\title{
Late Pleistocene and Holocene vegetation and climate on the northern Taymyr Peninsula, Arctic Russia
}

ANDREI A. ANDREEV, PAVEL E. TARASOV, CHRISTINE SIEGERT, TOBIAS EBEL, VLADIMIR A. KLIMANOV, MARTIN MELLES, ANATOLY A. BOBROV, ALEXANDR YU. DEREVIAGIN, DAVID J. LUBINSKI AND HANS-WOLFGANG HUBBERTEN

\section{BOREAS}

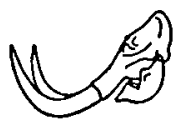

Andreev, A. A., Tarasov, P. E., Siegert, C., Ebel, T., Klimanov, V. A., Melles, M., Bobrov, A. A., Dereviagin, A. Yu., Lubinski, D. J. \& Hubberten H.-W. 2003 (September): Late Pleistocene and Holocene vegetation and climate on the northern Taymyr Peninsula, Arctic Russia. Boreas, Vol. 32, pp. 484-505. Oslo. ISSN 03009483.

Pollen data from a Levinson-Lessing Lake sediment core $\left(74^{\circ} 28^{\prime} \mathrm{N}, 98^{\circ} 38^{\prime} \mathrm{E}\right)$ and Cape Sabler, Taymyr Lake permafrost sequences $\left(74^{\circ} 33^{\prime} \mathrm{N}, 100^{\circ} 32^{\prime} \mathrm{E}\right)$ reveal substantial environmental changes on the northern Taymyr Peninsula during the last $c .32000{ }^{14} \mathrm{C}$ years. The continuous records confirm that a scarce steppe-like vegetation with Poaceae, Artemisia and Cyperaceae dominated c. 32000-10300 ${ }^{14} \mathrm{C} \mathrm{yr} \mathrm{BP,} \mathrm{while} \mathrm{tundra-like} \mathrm{vegetation} \mathrm{with}$ Oxyria, Ranunculaceae and Caryophyllaceae grew in wetter areas. The coldest interval occurred c. $18000 \mathrm{yr}$ BP. Lateglacial pollen data show several warming events followed by a climate deterioration $c .10500{ }^{14} \mathrm{C}$ yr $\mathrm{BP}$, which may correspond with the Younger Dryas. The Late Pleistocene/Holocene transition, c. 10300-10000 ${ }^{14} \mathrm{C}$ yr BP, is characterized by a change from the herb-dominated vegetation to shrubby tundra with Betula sect. Nance and Salix. Alnus fruticosa arrived locally c. $9000-8500{ }^{14} \mathrm{C}$ yr BP and disappeared c. $4000-3500{ }^{14} \mathrm{C}$ yr BP. Communities of Betula sect. Nanae, broadly distributed at $c$. $10000-3500{ }^{14} \mathrm{C}$ yr BP, almost disappeared when vegetation became similar to the modern herb tundra after $3500-3000{ }^{14} \mathrm{C}$ yr BP. Quantitative climate reconstructions show Last Glacial Maximum summer temperature about $4^{\circ} \mathrm{C}$ below the present and Preboreal $(c$. $10000{ }^{14} \mathrm{C}$ yr BP) temperature $2-4^{\circ} \mathrm{C}$ above the present. Maximum summer temperature occurred between 10000 and $5500{ }^{17} \mathrm{C}$ yr BP; later summers were similar to present or slightly warmer.

Andrei A. Andreev (e-mail: aandreev@awi-potsdam.de), Christine Siegert, Tobias Ebel and Hans-Wolfgang Hubberten, Alfred Wegener Institute for Polar and Marine Research, Research Unit Potsdam. Telegrafenberg A43, DE-14473 Potsdam, Germany; Pavel E. Tarasov, Geography Department of Moscow State University, Vorobievy Gon, 119899 Moscow, Russia; Vladimir A. Klimanov, Institute of Geography RAS, Staromonetny 29, 109017 Moscow, Russia; Martin Melles, Institute for Geophysics and Geology, University of Leipzig, Talstrasse 35, DE-04103 Leipzig, Germany; Anatoly A. Bobrov, Soil Department of Moscow State University, Vorobievy Gory, 119899 Moscow, Russia; Alexandr Yu. Dereviagin, Geology Department of Moscow State University, Vorobievy Gory, 119899 Moscow, Russia; David J. Lubinski, Institute of Arctic and Alpine Research, University of Colorado, CB 450, Boulder, Colorado, 80309-0450, USA; received 8th July 2002, accepted 14th November 2002.
Recent field-based studies on the Taymyr Peninsula have documented restricted Late Weichselian glaciation in central Siberia (e.g. Möller et al. 1999; Alexanderson et al. 2001; Mangerud et al. 2002), thereby disproving the mostly theoretically based maximum glaciation scenario (e.g. Grosswald 1998; Grosswald \& Hughes 2002). The environmental conditions associated with this minimal glacier cover, however, remain poorly understood. Better reconstruction of these environments requires longer and better-dated sediment sequences containing biological remains (i.e. pollen and macrofossils).

This article reconstructs vegetation and climate change on the northern Taymyr Peninsula based on new studies of long pollen sequences from LevinsonLessing Lake and Cape Sabler, Taymyr Lake (Fig. 1). These sequences were discovered in the 1990s as part of the multidisciplinary German-Russian research Project 'Taymyr' (Melles et al. 1996). We build on prior Project 'Taymyr' pollen work for LevinsonLessing Lake (Hahne \& Melles 1999) and macrofossil work for Cape Sabler (Kienast et al. 2001) by generating additional pollen data, developing much better age models, performing quantitative environmental reconstruction, and revising the pollen-based interpretations. Moreover, we compare our new records with others assembled for Project 'Taymyr' (Hahne \& Melles 1997; Kienel et al. 1999; Siegert et al. 1999; Andreev et al. 2002b; Andreev et al. in press) and with the published environmental records from adjacent areas of Taymyr (Belorusova \& Ukraintseva 1980; Nikol'skaya 1980; Nikol'skaya et al. 1980; Andreeva \& Kind 1982; Belorusova et al. 1987; Velichko et al. 1997; Andreev \& Klimanov 2000). This comparison gives a detailed picture of environmental changes on the northern Taymyr Peninsula since $c .32000{ }^{14} \mathrm{C}$ yr BP.

\section{Study area}

\section{Levinson-Lessing Lake}

Levinson-Lessing Lake $\left(74^{\circ} 28^{\prime} \mathrm{N}, 98^{\circ} 38^{\prime} \mathrm{E} ; 47 \mathrm{~m}\right.$ a.s.l.) 
Fig. 1. A. Map of the Arctic. B. Map of Taymyr-Severnaya Zemlya region. C. Overview map of the Levinson-Lessing Lake area with coring site. Bathymetry in $\mathrm{m}$. D. Overview map of the Cape Sabler area with sampled sites.

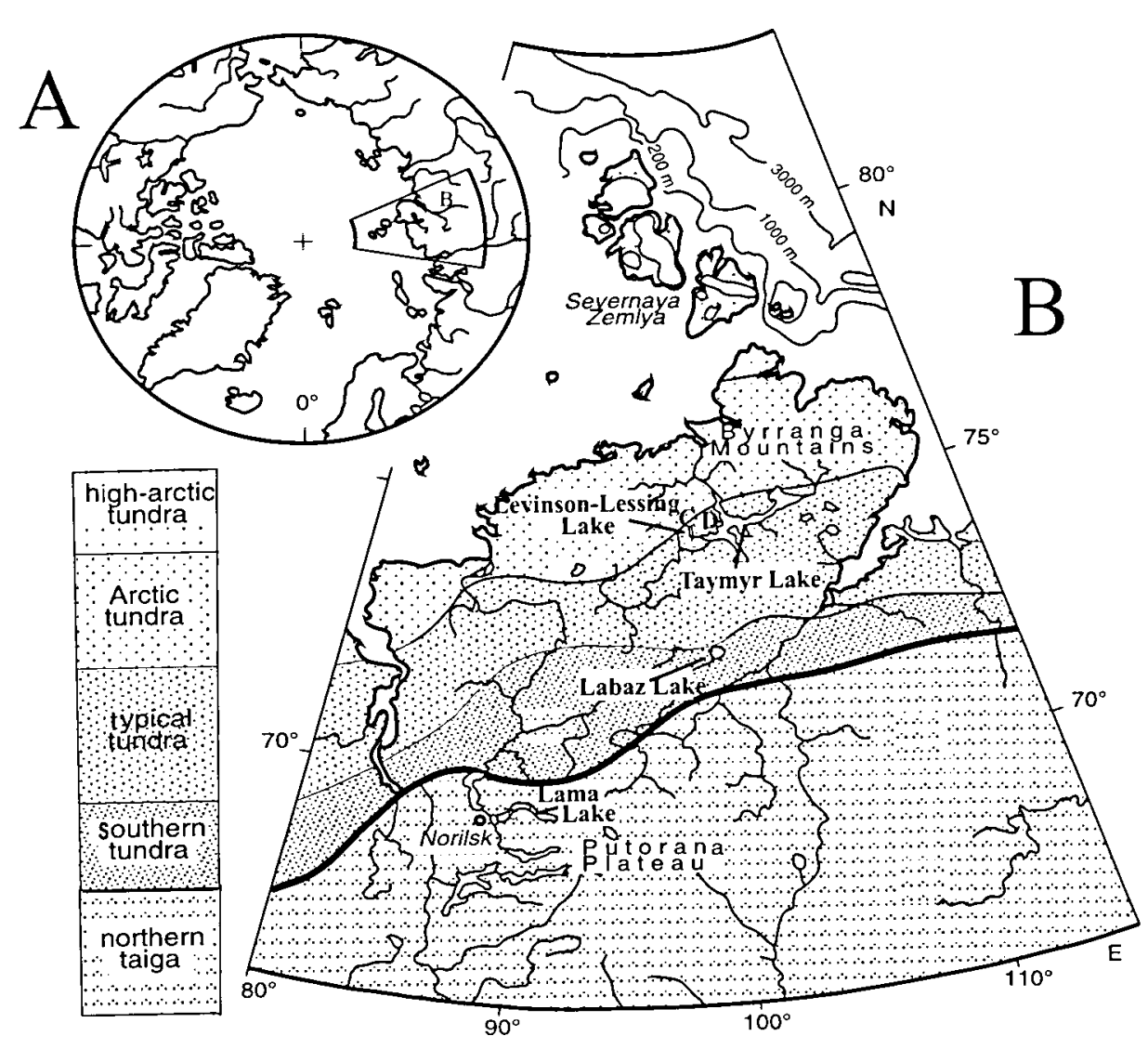

is the deepest lake $(110 \mathrm{~m})$ of the northern Taymyr Peninsula and lies within the limits of the Glavnyi Range, Byrranga Mountains (Fig. 1). The hills surrounding the lake reach altitudes up to $570 \mathrm{~m}$ a.s.l. The lake basin is $15 \mathrm{~km}$ long and $1-2 \mathrm{~km}$ wide, covering an area of $c .25 \mathrm{~km}^{2}$. Inflow occurs via the Krasnaya River in the north and by numerous small streams on the relatively steep eastern and western slopes. Outflow is by the Protochnaya River in the south. The geomorphology of the lake area reflects its tectonic origin, reshaped by glacial erosion presumably during the early Weichselian (Anisimov \& Pospelov 1999; Niessen et al. 1999). Bedrock is composed of terrigeneous Permian rocks (auleurolites) with intrusions of dolerites (Bolshiyanov \& Anisimov 1995).

The continental Arctic climate in the lake basin includes long, severe winters and short summers. July temperature $\left(\mathrm{T}_{\mathrm{VII}}\right)$ is only $5-7^{\circ} \mathrm{C}$, while January temperature $\left(\mathrm{T}_{\mathrm{I}}\right)$ is about -33 to $-35^{\circ} \mathrm{C}$. Mean annual temperature $\left(\mathrm{T}_{\mathrm{yr}}\right)$ is about $-15^{\circ} \mathrm{C}$. Annual precipitation $\left(\mathrm{P}_{\mathrm{yr}}\right)$ reaches $250 \mathrm{~mm}$, with a maximum in summer (Atlas Arktiki 1985).

The lake basin lies within the zone of continuous permafrost, up to $500 \mathrm{~m}$ thick (Geokriologia SSSR 1989). Active layer thickness ranges from $20-30 \mathrm{~cm}$ in peatlands to $1 \mathrm{~m}$ in gravelly sediments without vegetation cover. Diverse types of gleysols dominate the lake surroundings, depending on the moisture regime (Anisimov \& Pospelov 1999).

Levinson-Lessing Lake is situated at the border between the Subarctic and Arctic tundra zones. Vegetation varies from mountain desert with sparse lichen-herb cover to moss-forb tundra with discontinuous vegetation at high elevations, and dry sedge-forb tundra with dominant Dryas octopetala, Salix polaris and Cassiope tetragona (Anisimov \& Pospelov 1999). In some places, vegetation is of steppe-like character with grasses dominating. The largest plant diversity occurs in the marginal meadows on the lowest Krasnaya River terrace. Willow shrubs (Salix arctica, S. reptans, S. pulchra) are sparsely distributed (Zhurbenko 1995).

\section{Cape Sabler Peninsula}

The Cape Sabler Peninsula $\left(74^{\circ} 33^{\prime} \mathrm{N}, 100^{\circ} 32^{\prime} \mathrm{E}\right)$ is located on the northwestern shore of Taymyr Lake, about $50 \mathrm{~km}$ east of Levinson-Lessing Lake (Fig. 1). A number of shallow lakes separate the peninsula from a low elevation portion of the Byrranga Mountains 


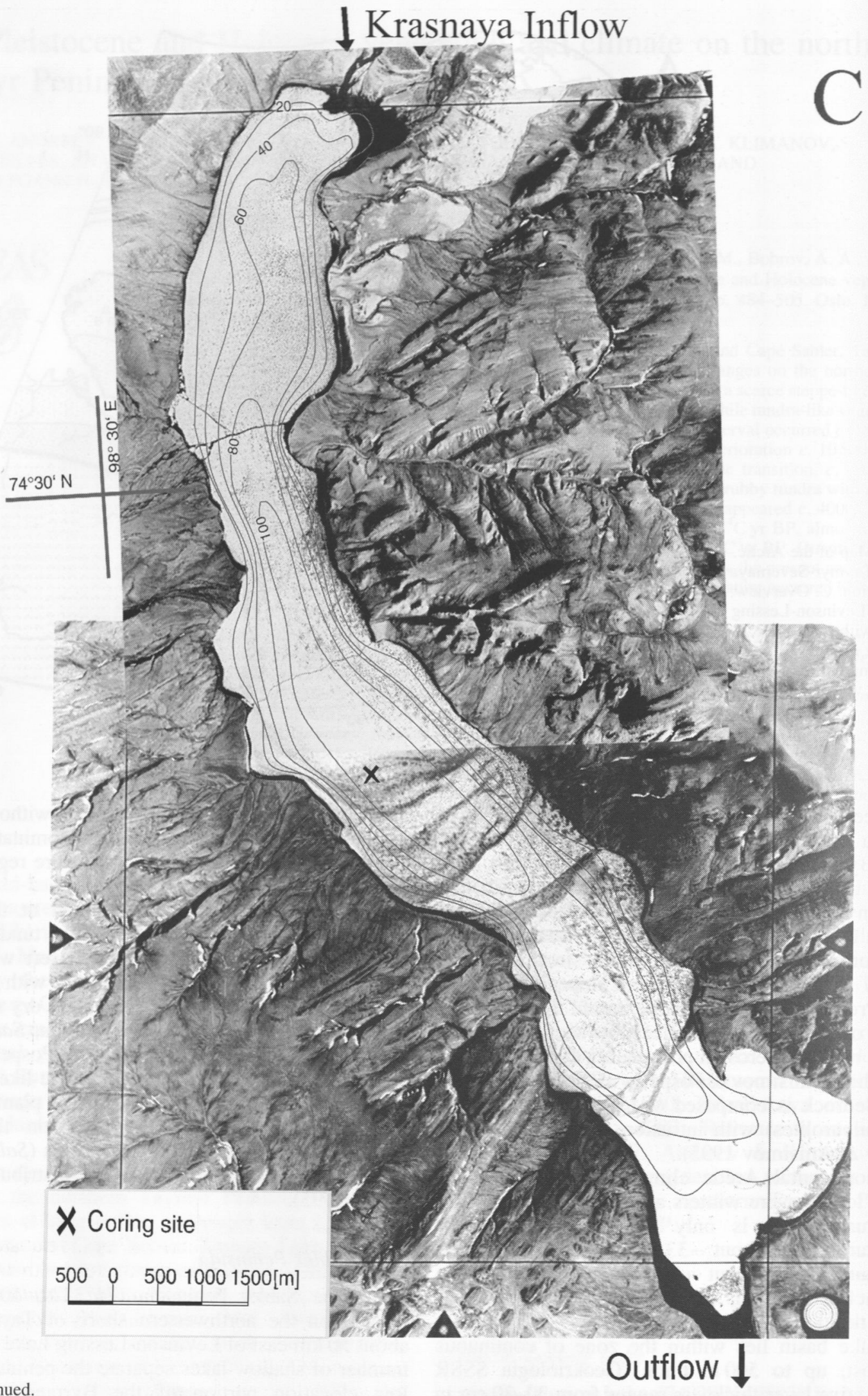



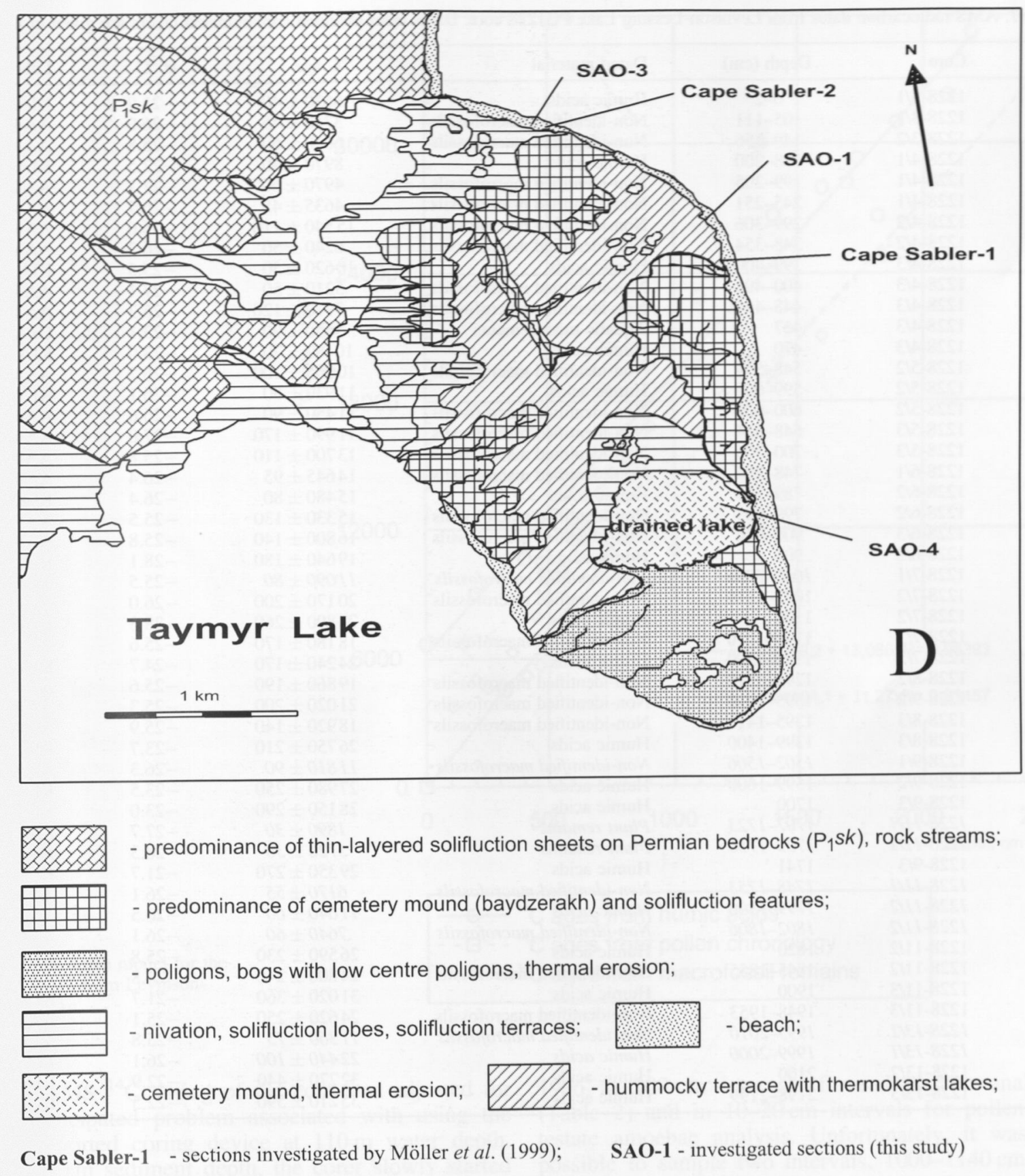

Fig. 1. Continued.

(Derevyagin et al. 1997). Permafrost features are widespread and include frost cracks, polygonal ground, ice wedges, thermokarst depressions, solifluction and nivation forms. The peninsula shoreline consists of silty cliffs up to $25 \mathrm{~m}$ high (Derevyagin et al. 1997; Möller et al. 1999).

The Cape Sabler Peninsula has similar climate, soil and permafrost characteristics as the Levinson-Lessing
Lake area (Atlas Arktiki 1985). The Peninsula is situated within the northern belt of the Subarctic tundra. Herb-dwarf-shrub tundra dominates, with Dryas punctata, Salix polaris, S. nummularia, Luzula nivalis and Carex ensifolia and mosses like Hylocomium alaskianum and Drepanocladus incinatus. Sparse shrub communities of Salix arctica, S. reptans, S. pulchra and Betula nana are also present. 
Table 1. AMS radiocarbon dates from Levinson-Lessing Lake PG1228 core. Dates from assumed contaminated layers are given in italics.

\begin{tabular}{|c|c|c|c|c|c|c|}
\hline $\mathrm{NN}$ & Core & Depth $(\mathrm{cm})$ & Dated material & ${ }^{14} \mathrm{C}$ age & $\partial^{13} \mathrm{C}$ & Lab. no. \\
\hline 1 & $1228-3 / 1$ & $0-2$ & Humic acids & $6630 \pm 40$ & -21.9 & KIA3312 \\
\hline 2 & $1228-3 / 1$ & $105-111$ & Non-identified macrofossils & $3740 \pm 45$ & -26.0 & AA40891 \\
\hline 3 & $1228-3 / 2$ & $149-156$ & Non-identified macrofossils & $6640 \pm 60$ & -25.8 & AA40892 \\
\hline 4 & $1228-4 / 1$ & $198-200$ & Humic acids & $8970 \pm 40$ & -27.5 & KIA3313 \\
\hline 5 & $1228-4 / 1$ & $199-205$ & Non-identified macrofossils & $4970 \pm 60$ & -27.1 & AA40893 \\
\hline 6 & $1228-4 / 1$ & $245-251$ & Non-identified macrofossils & $4635 \pm 45$ & -26.7 & AA40894 \\
\hline 7 & $1228-4 / 2$ & $299-306$ & Non-identified macrofossils & $15540=110$ & -25.0 & AA40895 \\
\hline 8 & $1228-4 / 2$ & $348-354$ & Non-identified macrofossils & $6240 \pm 50$ & -26.3 & AA40896 \\
\hline 9 & $1228-4 / 3$ & $399-400$ & Humic acids & $10620 \pm 50$ & -25.5 & KIA3314 \\
\hline 10 & $1228-4 / 3$ & $400-406$ & Non-identified macrofossils & $5210 \pm 50$ & -27.1 & AA40897 \\
\hline 11 & $1228-4 / 3$ & $448-454$ & Non-identified macrofossils & $7970 \pm 120$ & -26.3 & AA40898 \\
\hline 12 & $1228-4 / 3$ & 467 & Aquatic moss remains & $5650 \pm 90$ & -23.1 & OxA-6526 \\
\hline 13 & $1228-4 / 3$ & 470 & Humic acids & $10480 \pm 70$ & -23.0 & KIA5289 \\
\hline 14 & $1228-5 / 2$ & $548-554$ & Non-identified macrofossils & $10065 \pm 100$ & -26.2 & AA40899 \\
\hline 15 & $1228-5 / 2$ & $599-600$ & Humic acids & $11930 \pm 50$ & -26.1 & KIA3315 \\
\hline 16 & $1228-5 / 2$ & $600-606$ & Non-identified macrofossils & $11450 \pm 90$ & -26.6 & AA40900 \\
\hline 17 & $1228-5 / 3$ & $648-654$ & Non-identified macrofossils & $11990 \pm 170$ & -27.0 & AA40901 \\
\hline 18 & $1228-5 / 3$ & $700-706$ & Non-identified macrofossils & $13700 \pm 110$ & -25.8 & AA40902 \\
\hline 19 & $1228-6 / 1$ & $748-756$ & Non-identified macrofossils & $14645 \pm 95$ & -26.4 & AA40903 \\
\hline 20 & $1228-6 / 2$ & $789-799$ & Humic acids & $15480 \pm 80$ & -26.4 & KIA3316 \\
\hline 21 & $1228-6 / 2$ & $799-803$ & Non-identified macrofossils & $15330 \pm 130$ & -25.5 & AA40904 \\
\hline 22 & $1228-6 / 3$ & $900-906$ & Non-identified macrofossils & $16800 \pm 140$ & -25.8 & AA40905 \\
\hline 23 & $1228-6 / 3$ & 904 & Humic acids & $19640 \pm 180$ & -28.1 & KIA5290 \\
\hline 24 & $1228-7 / 1$ & $1000-1006$ & Non-identified macrofossils & $11090 \pm 80$ & -25.5 & AA40906 \\
\hline 25 & $1228-7 / 2$ & $1095-1110$ & Non-identified macrofossils & $20170 \pm 200$ & -26.0 & AA40907 \\
\hline 26 & $1228-7 / 2$ & 1100 & Humic acids & $22890 \pm 260$ & -28.3 & KIA5291 \\
\hline 27 & $1228-7 / 3$ & $1195-1210$ & Non-identified macrofossils & $18180 \pm 170$ & -25.6 & AA40908 \\
\hline 28 & $1228-7 / 3$ & $1199-1200$ & Humic acids & $24240 \pm 170$ & -24.7 & KIA3318 \\
\hline 29 & $1228-8 / 2$ & $1295-1310$ & Non-identified macrofossils & $19860 \pm 190$ & -25.6 & AA40909 \\
\hline 30 & $1228-9 / 2$ & $1595-1610$ & Non-identified macrofossils & $21020 \pm 200$ & -25.3 & AA40912 \\
\hline 31 & $1228-8 / 3$ & $1395-1410$ & Non-identified macrofossils & $18920 \pm 140$ & -25.9 & AA40910 \\
\hline 32 & $1228-8 / 3$ & $1399-1400$ & Humic acids & $26750 \pm 210$ & -23.7 & KIA3319 \\
\hline 33 & $1228-9 / 1$ & $1502-1506$ & Non-identified macrofossils & $11810 \pm 90$ & -26.3 & AA409II \\
\hline 34 & $1228-9 / 2$ & $1599-1600$ & Humic acids & $27980 \pm 250$ & -23.5 & KIA3320 \\
\hline 35 & $1228-9 / 3$ & 1700 & Humic acids & $28150 \pm 290$ & -23.0 & KIA5292 \\
\hline 36 & $1228-I 1 / 1$ & $1707-1723$ & Plant remains & $1890 \pm 30$ & -27.7 & KIA $140 I$ \\
\hline 37 & $1228-11 / 1$ & $1723-1750$ & Plant remains & $3720 \pm 30$ & -28.3 & KIA 1402 \\
\hline 38 & $1228-9 / 3$ & 1741 & Humic acids & $29350 \pm 270$ & -21.7 & KIA5293 \\
\hline 39 & $1228-11 / 1$ & $1748-I 753$ & Non-identified macrofossils & $6170 \pm 55$ & -26.1 & AA409I3 \\
\hline 40 & $1228-11 / 2$ & $1799-1800$ & Humic acids & $11640 \pm 60$ & -26.5 & $K I A 332 I$ \\
\hline 41 & $1228-11 / 2$ & $1802-1806$ & Non-identified macrofossils & $7640 \pm 60$ & -26.1 & $A A 40914$ \\
\hline 42 & $1228-11 / 2$ & 1820 & Humic acids & $26590 \pm 230$ & -25.8 & KIA5294 \\
\hline 43 & $1228-11 / 2$ & $1845-1855$ & Non-identified macrofossils & $24800 \pm 240$ & -24.8 & AA40915 \\
\hline 44 & $1228-11 / 3$ & 1900 & Humic acids & $31020 \pm 360$ & -21.7 & KIA5295 \\
\hline 45 & $1228-11 / 3$ & $1948-1953$ & Non-identified macrofossils & $24620 \pm 250$ & -25.1 & AA40916 \\
\hline 46 & $1228-13 / 1$ & $1995-2010$ & Non-identified macrofossils & $11360 \pm 75$ & -25.8 & $A A 40917$ \\
\hline 47 & $1228-13 / 1$ & $1999-2000$ & Humic acids & $22440 \pm 100$ & -26.1 & KIA3322 \\
\hline 48 & $1228-13 / 2$ & 2100 & Humic acids & $32270 \pm 440$ & -22.9 & KIA5296 \\
\hline 49 & $1228-13 / 3$ & $2198-2199$ & Humic acids & $35210 \pm 590$ & -22.5 & KIA3323 \\
\hline
\end{tabular}

\section{Methods}

\section{Sampling, radiocarbon and pollen methods}

Piston core PG1228 (2210-cm-long) was collected from the central part of Levinson-Lessing Lake at $108 \mathrm{~m}$ water depth when ice cover was $2 \mathrm{~m}$ thick during the spring of 1995 (Fig. 1; Melles et al. 1994; Overduin et al. 1996). A gravity corer was used at the same site to recover the uppermost sediments $(0-27 \mathrm{~cm})$ with minimal disturbance of the water-sediment interface.
A pollen sampling interval of $10-20 \mathrm{~cm}$ was used for the upper $980 \mathrm{~cm}$ of the core, and $50 \mathrm{~cm}$ for most of the deposits below (except $20 \mathrm{~cm}$ for $1680-1820 \mathrm{~cm}$ and $10 \mathrm{~cm}$ for $1840-2000 \mathrm{~cm}$ depths). Sampling intervals for AMS ${ }^{14} \mathrm{C}$ dating of macrofossil remains (Table 1) were $c .50 \mathrm{~cm}$ for the upper $800 \mathrm{~cm}$ of the core and $c$. $100 \mathrm{~cm}$ in the deposits below (except $c .50 \mathrm{~cm}$ between the 1748 and $1855 \mathrm{~cm}$ depth). Additional ${ }^{14} \mathrm{C}$ dating was conducted on humic acids, extracted from 19 samples, using $\mathrm{KOH}$ for extraction and $\mathrm{HCl}$ for cleaning. 
Fig. 2. Age/depth model for the core PG1228 from LevinsonLessing Lake.

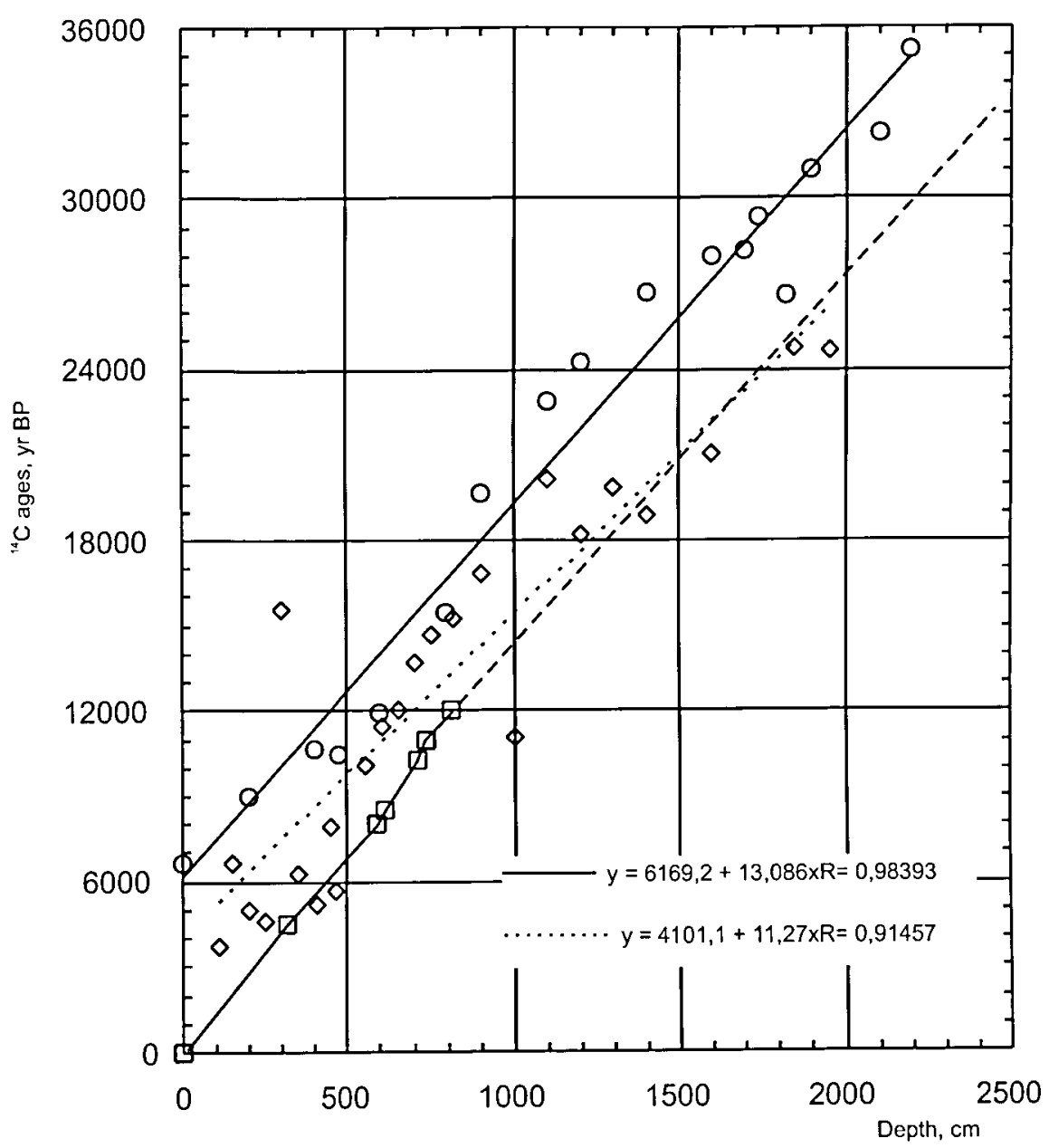

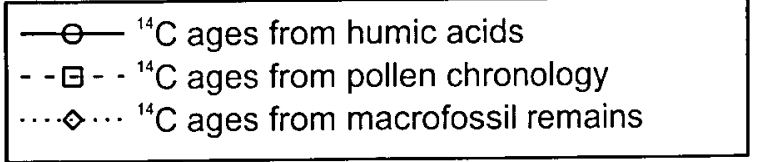

The AMS ${ }^{14} \mathrm{C}$ dating of the core was adjusted for an unanticipated problem associated with using the rope-supported coring device at $110 \mathrm{~m}$ water depth. Below $10 \mathrm{~m}$ sediment depth, the corer slowly started to open before the intended depth; this problem potentially allowed sediments from the upper third of each 3-m section (below $10 \mathrm{~m}$ sediment depth) to be displaced. Sediment below approximately $1 \mathrm{~m}$ in each 3-m section appears to lie at the correct depth. All potentially displaced ${ }^{14} \mathrm{C}$ samples (italicized, Table 1) were not considered for the age-depth model (Fig. 2). We have also excluded pollen data corresponding to the potentially displaced material from interpretation.

The 27-m sediment section from Cape Sabler, SAO-1 (Fig. 1; Derevyagin et al. 1997) was sampled in summer
1996 at $100-\mathrm{cm}$ intervals for radiocarbon analyses (Table 2) and in $10-20 \mathrm{~cm}$ intervals for pollen and testate amoebae analysis. Unfortunately, it was not possible to sample two intervals, $1000-1140 \mathrm{~cm}$ and $1770-2100 \mathrm{~cm}$, because of sediment disturbance. Additional pollen samples at $10-20 \mathrm{~cm}$ intervals were taken from a $270-\mathrm{cm}-$ long section (SAO-3) and a $310-\mathrm{cm}$ long section (SAO-4) (Fig. 1). Four levels were sampled for radiocarbon dating from these short sections (Table 2).

Two methods were used to process the pollen samples. Most of the SAO samples started with a heavy-liquid separation (Berglund \& Ralska-Jasiewiczowa 1986) followed by acetolysis and glycerin mounting (analyses by G. N. Shilova, Moscow State University). Additional samples from section SAO-I 
Table 2. Conventional and AMS radiocarbon dates from Cape Sabler terrestrial profiles: SAO-1, SAO-3 and SAO-4. Dates not used for the reconstructions are given in italics.

\begin{tabular}{|c|c|c|c|c|c|c|}
\hline NN & Section & Depth $(\mathrm{cm})$ & Dated material & ${ }^{14} \mathrm{C}$ age & $\partial^{1.3} \mathrm{C}$ & Lab. no. \\
\hline l & $S A O-I$ & $70-80$ & Peat & $2270 \pm 80$ & -26.0 & $A W I-96-1$ \\
\hline 2 & SAO-1 & 130 & Sedge peat & $1575 \pm 20$ & -25.8 & KIA5745 \\
\hline 3 & SAO-1 & $160-170$ & Sedge-moss peat & $2700 \pm 25$ & -27.1 & KIA5746 \\
\hline 4 & SAO-1 & $260-270$ & Plant remains & $6730 \pm 30$ & -26.7 & KIA 5747 \\
\hline 5 & SAO-1 & $300-350$ & Peat & $10170 \pm 130$ & -25.0 & AWI-96-2 \\
\hline 6 & SAO-1 & $500-600$ & Peat with small twigs & $12310 \pm 170$ & -26.3 & AWI-96-3 \\
\hline 7 & $\mathrm{SAO}-1$ & 570 & Plant remains & $11855 \pm 50$ & -27.1 & KIA5748 \\
\hline 8 & SAO-I & $1000-1050$ & Peat with small twigs & $18220 \pm 320$ & & AWI-96-4 \\
\hline 9 & $S A O-I$ & 1320 & Moss peat & $19020 \pm 300$ & & AWII-96-5 \\
\hline 10 & SAO-I & 1320 & Salix leaves & $18065 \pm 60$ & -26.4 & KIA5749 \\
\hline 12 & SAO-I & $1500-1550$ & Plant remains & $19520 \pm 270$ & -26.6 & AWI-96-6 \\
\hline 13 & SAO-1 & 2100 & Peat & $26750 \pm 650$ & -27.0 & AWI-96-7 \\
\hline 14 & SAO-I & 2100 & Moss peat & $30300+180 /-170$ & -25.8 & KIA5750 \\
\hline 15 & $S A O-I$ & 2180 & Shrub twigs & $29540 \pm 790$ & -26.4 & $A W I-96-8$ \\
\hline 16 & $S A O-I$ & 2310 & $\begin{array}{l}\text { Alkaline residue of woody remains and roots } \\
\text { Humid acids, woody and non-identified plant remains }\end{array}$ & $\begin{array}{l}32060+220 /-210 \\
26720 \pm 150\end{array}$ & -25.5 & KIA575I \\
\hline 17 & SAO-1 & 2500 & Roots, non-identified aquatic plants remains & $29960 \pm 790$ & -25.5 & AWI-96-10 \\
\hline 19 & SAO-1 & 2520 & Alkaline residue of woody and non-identified plant remains & $30760+210 /-200$ & & KIA5752 \\
\hline 20 & $\mathrm{SAO}-3$ & 120 & Non-identified plant remains & $2060 \pm 110$ & & AWI-96-11 \\
\hline 21 & SAO-3 & 140 & Non-identified plant remains & $2340 \pm 70$ & -27.0 & AWI-96-12 \\
\hline 22 & SAO-3 & 265 & Non-identified plant remains & $4380 \pm 90$ & -23.4 & AWI-96-13 \\
\hline 23 & $\mathrm{SAO}-4$ & $70-80$ & Peat with woody remains & $2820 \pm 60$ & -26.3 & AWI-96-14 \\
\hline
\end{tabular}

and all samples from core PG1228 were processed using standard HF techniques (Hahne \& Melles 1999).

Pollen percentages are based as follows: (1) arboreal and non-arboreal pollen taxa from the sum of terrestrial pollen taxa; (2) spores from the sum of pollen and spores; (3) redeposited taxa - Tertiary spores and redeposited pollen - from the sum of pollen and redeposited taxa; and (4) algae from the sum of pollen and algae (Berglund \& Ralska-Jasiewiczowa 1986). Calculations and plotting were performed with Tilia/ TiliaGraph software (Grimm 1991).

Testate amoebae were extracted from sediments with a $500-\mu \mathrm{m}$ sieve. A drop of the concentrate was placed on a slide, then glycerol was added. Normally, 5 subsamples were examined at $200-400 \times$ magnification with a light microscope.

\section{Climate reconstruction methods}

To quantitatively reconstruct climate from the pollen records, two statistical techniques were used: (1) the statistical-information (IS) method and (2) the best modern analogue (BMA) method. The IS method (Klimanov 1984; Velichko et al. 2002) determines the statistical relationship between recent pollen spectra and climate and then applies this relationship to fossil pollen records to reconstruct past environments. Specifically, it uses the total pollen/spore ratio as well as the relative abundance of the 14 most common arboreal taxa. Because the method is mostly based on statistical correlations between arboreal pollen and climate, reconstructions in treed areas and treed time intervals are more reliable than treeless areas (like the northern
Taymyr) and treeless time (like the Late Weichselian). Despite these problems, the IS reconstruction for the Late Pleistocene on northern Taymyr Peninsula remains helpful; as it shows consistent climate trends.

The BMA method (Guiot 1990) was used to reconstruct climate changes from the PG1228 pollen record. The method uses chord distances to determine the similarity between each analysed pollen spectrum and each spectrum in the reference pollen data set of 1110 modern pollen samples collected in the former USSR and Mongolia territories (Tarasov et al. 1998, 2002). In this study, minimum and maximum values for each climate variable were reconstructed from the 10 best modern analogues determined for each fossil sample. Table 3 lists the 39 pollen taxa identified in the PG1228 record that have been used in the climate reconstructions. Modern climate values for each of the 1110 modern pollen sampling sites have been calculated from an updated version of the climate database of

Table 3. Pollen taxa identified in the Levinson-Lessing record and used in the climate reconstruction by the BMA method.

Taxa name

Alnus undif., Apiaceae, Artemisia, Asteraceae undif., Betula undif., Boraginaceae, Brassicaceae, Caryophyllaceae, Chenopodiaceae, Cyperaceae, Dipsacaceae, Dryas, Ephedra, Ericales, Fabaceae, Gentianaceae, Hippophae, Juniperus, Lamiaceae, Larix, Liliaceae, Onagraceae, Papaveraceae, Picea, Pinus (Diploxylon), Pinus (Haploxylon), Plantaginaceae, Poaceae, Polygonaceae, Populus, Ranunculaceae, Rosaceae, Rumex, Rubiaceae, Salix, Saxifragaceae, Scrophulariaceae, Thalictrum, Valerianaceae 
Leemans \& Cramer (1991) with precise topography (W. Cramer, pers. comm. 2001). PPBase software facilitated the calculations (Guiot \& Goeury 1996; http://medias. obs-mip.fr/paleo_utils).

Because the BMA method takes into account arboreal as well as non-arboreal pollen it has better potential than the IS method for treeless areas such as northern Taymyr. Nevertheless, we did not apply the method either to the lower part of the Levinson-Lessing record or to the Cape Sabler pollen data because of low pollen concentration and potential sediment displacement discussed above.

How much can we trust quantitative climate reconstructions based on pollen data? This question is especially important for the Russian Arctic, a region where an appropriate database of the reference surface samples is still under construction. Past studies assessed the reliability of the climate reconstruction techniques for northern Eurasia by reconstructing present-day climate characteristics from modern pollen spectra. Reported errors in the IS method were $\pm 0.6^{\circ} \mathrm{C}$ for $\mathrm{T}_{\mathrm{yr}}$ and $\mathrm{T}_{\mathrm{VII}} ; \pm 1.0^{\circ} \mathrm{C}$ for $\mathrm{T}_{\mathrm{I}} ;$ and $\pm 25 \mathrm{~mm}$ for $\mathrm{P}_{\mathrm{yI}}$ (Klimanov 1984). However, these results were obtained with the data sets in which the Arctic was poorly represented.

Recent tests demonstrate that the BMA method reconstructs modern climate variables in the Arctic with reasonably high accuracy (Tarasov et al. 2002; Andreev et al. in prep.). Correlation coefficients between reconstructed and calculated climate variables have suggested that $\mathrm{T}_{\mathrm{VII}}$ and annual sum of the day temperatures above $5^{\circ} \mathrm{C}$ (the so-called sum of growingdegree-days with temperatures above $5^{\circ} \mathrm{C}$, GDD5) can be reconstructed with reasonably high confidence ( $R=0.80$ and 0.82 , respectively). Among the other tested variables, $P$ and runoff (difference between $P$ and evaporation $(E)$ ) were reconstructed from the modern spectra with relatively high accuracy $(R=0.68$ and 0.61 , respectively).

In this study, the methods have been applied together only to the upper part of the PG1228 pollen record covering the last 17000 years. We assumed that in this record the above-mentioned problems (e.g. low pollen concentration or non-arboreal pollen dominance) can be neglected, as their influence on the reconstructions is supposed to be minimized. However, the absolute climate values obtained from the pollen records dated before $20000 \mathrm{yr}$ BP for the northern Taymyr Peninsula are suspect and thus have not been plotted on any figure.

\section{Results}

\section{Levinson-Lessing Lake}

Lithology and stratigraphy. - Core PG1228 consists of two main sediment types (Ebel et al. 1999). Finegrained laminae $(c .0 .7 \mathrm{~mm})$ constitute about $80 \%$ of the core and consist of couplets with silt-sized basal and clay-sized top layers. These regular laminae probably represent annual layers. The remaining $20 \%$ of the core is comprised of sandy layers, which occur irregularly throughout the sequence. The thickness of these layers varies between $2 \mathrm{~mm}$ and $20 \mathrm{~cm}$; they are derived from collapses of delta front sediments and subsequent downslope sediment transport to the lake centre (Ebel et al. 1999). The sediments throughout the core appear to be continuously deposited; there is no evidence of erosion or non-deposition.

Chronology. - In total, 49 samples from core PG1228 were AMS ${ }^{14} \mathrm{C}$ dated (Table 1; all ages are uncalibrated). Our age-depth model for this core is based on correlation with a regional pollen chronology for the upper $8 \mathrm{~m}$ of the core and macrofossil dates below $12 \mathrm{~m}$. Corrected humic acid dates provide age constraint throughout the core, but particularly in the gap between 8 and $12 \mathrm{~m}$.

Although the macrofossils picked throughout the core were expected to provide reliable dates, many are 100 old and only give maximum age constraints (Fig. 2). On average they deviate by $c .2500 \mathrm{yr}$ from a ${ }^{14} \mathrm{C}$ constrained Holocene pollen chronology for adjacent areas on the Taymyr Peninsula (Belorusova \& Ukraintseva 1980; Nikol'skaya 1980; Nikol'skaya et al. 1980; Andreeva \& Kind 1982; Belorusova et al. 1987; Clayden et al. 1997; Velichko et al. 1997; Andreev \& Klimanov 2000; Andreev et al. 2002b; Andreev et al. in press). This large discrepancy probably reflects a high content of reworked organic matter in the mostly unidentified macrofossil samples (including Permian coal fragments) and occasional visible sediment disturbance.

To help resolve the dating problems, a narrow fraction of humic acids was extracted from the bulk sediment at 19 levels throughout the core. The resulting humic acid ages (Table 2) are consistently 4000 to 6000 years older than the regional Holocene pollen chronology (Fig. 2). A similar offset is observed between humic acids and macrofossils in the lower half of the core. These lower macrofossil ages are, in turn, consistent with an extrapolation of the overall regional pollen chronology. Assuming a constant age offset for the humic acids, the basal age for the core is estimated at $c$. $33000{ }^{14} \mathrm{C}$ yr BP (Fig. 2).

Sedimentation rates appear to have an approximately linear trend in the core. Nevertheless, all three age constraints (humic, pollen chronology and macrofossils) suggest at least one deviation from this linear trend some time between about 600 and $1200 \mathrm{~cm}$ sediment depth; thus, slower rates occurred for an unknown duration some time between $c .17000$ and c. 8,000 ${ }^{14} \mathrm{C}$ yr BP).

Pollen. - The pollen diagram for core PG1228 from Levinson-Lessing Lake was zoned by visual inspection 


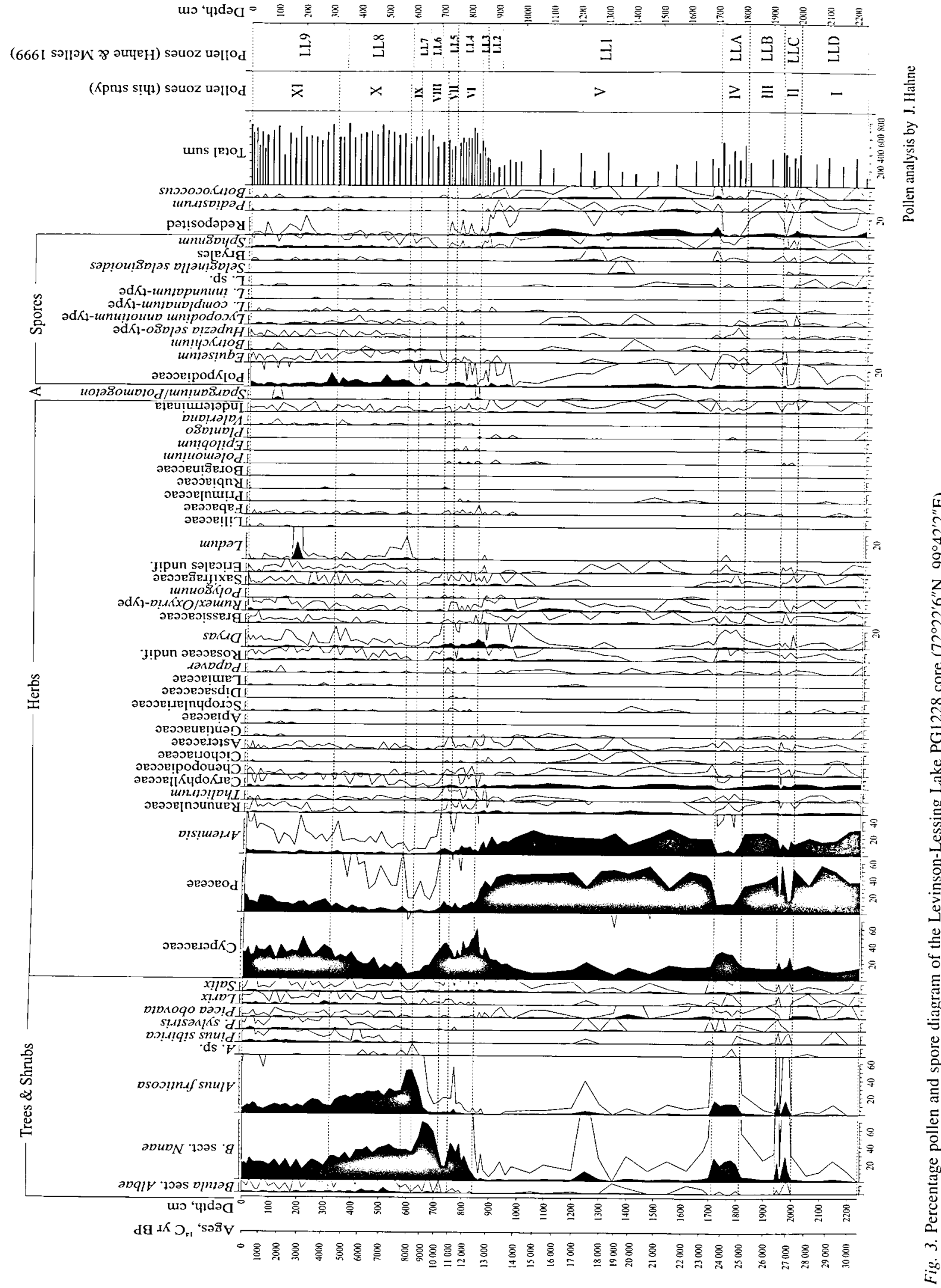


(Fig. 3). The basal pollen zone I (PZ-I) is notable for its very low pollen concentration (up to 500 grains per $\mathrm{cm}^{3}$ ). Its spectra are dominated by Artemisia, Poaceae, Cyperaceae and Caryophyllaceae. PZ-II $(2200-1940 \mathrm{~cm})$ is characterized by two peaks of Betula sect. Nanae, Almus fruticosa and Cyperaceae pollen. PZ-II was excluded, however, from further interpretation because of potential sediment displacement. PZ-III $(1940-1810 \mathrm{~cm})$ is similar to PZ-I. The pollen spectra of PZ-IV $(1810-1710 \mathrm{~cm})$ are dominated by Betula sect. Nanae, Alnus fruticosa and Cyperaceae pollen. Pollen concentration is relatively high (up to 5000 grains per $\mathrm{cm}^{3}$ ). PZ-IV was also excluded from further interpretation because of potential sediment displacement. The pollen content of PZ-V $(1710-1280 \mathrm{~cm})$ is similar to that of PZ-I and PZ-III. A lower sample at $1240 \mathrm{~cm}$ is characterized by high contents of Betula sect. Nanae, Alnuts fruticosa and Cyperaceae pollen, while Poaceae and Caryophyllaceae contents are low. The upper part of PZ-V is characterized by a gradual decrease of Artemisia and Poaceae pollen percentages, while Cyperaceae and Rosaceae (mostly Dryas) increase. PZ-VI $(850-750 \mathrm{~cm})$ is notable for a dramatic increase in Betula sect. Nanae and Cyperaceae pollen contents, and a decrease in Artemisia, Caryophyllaceae and Poaceae. Pollen concentration increases significantly (up to 15000 grains per $\mathrm{cm}^{3}$ ) in this zone. PZ-VII $(750-710 \mathrm{~cm})$ is characterized by increasing Cyperaceae, Poaceae, Caryophyllaceae, Artemisia and other herbs, whereas Betula sect. Nanae decreases. Pollen concentrations are significantly lower in this zone than in PZ-VI (up to 5000 grains per $\mathrm{cm}^{3}$ ). In PZ-VIII (710$660 \mathrm{~cm}$ ) Betula sect. Nanae pollen percentages dramatically increase (up to 65\%), whereas herbs decrease. Total pollen concentration is up to 20000 grains per $\mathrm{cm}^{3}$ in this zone. PZ-IX $(660-595 \mathrm{~cm})$ is notable for a dramatic increase (up to $52 \%$ ) in Alnus fruticosa pollen content and a significant decrease in Betula sect. Nanae one. Pollen concentration is at its maximum (up to 48000 grains per $\mathrm{cm}^{3}$ ) in this zone. PZ-X (595$315 \mathrm{~cm}$ ) is characterized by a gradual decrease of Betula sect. Nanae and Alnus fruticosa pollen contents, whereas Cyperaceae and Poaceae gradually increase. In this zone, pollen concentration is relatively high (up to 8000 grains per $\mathrm{cm}^{3}$ ). The pollen spectra of PZ-XI $(315-0 \mathrm{~cm})$ are dominated by pollen of Cyperaceae, Poaceae, Betula sect. Nanae, and Alnus fruticosa. Pollen concentration is lower in this zone than in PZ-X.

\section{Cape Sabler sections}

Lithology. - SAO1. The 27-m-high section of the lake terrace is of lacustrine sediments (Derevyagin et al. 1997). The predominating facies is laminated, or massive silt, mostly rich in plant detritus (moss remains, woody twigs, seeds and other plant remains). In the basal part of the section there is an interbedding of clay and fine sand beds. Thick (up to $1.2 \mathrm{~m}$ ) peaty layers with high silt content characterize the sequence (Figs 4, 5). For detailed lithological, geomorphological and stratigraphical descriptions of the SAOl section and the terrace, see Derevyagin et al. (1997) and Möller et al. (1999).

$\mathrm{SAO}$. The lower part of the section $(310-120 \mathrm{~cm})$ is composed of interbedded fine-grained grey sand and silt layers, including numerous peaty layers with plant remains (Fig. 6). At 120-100 cm depth, sand with moss and other plant remains is common. The upper $100 \mathrm{~cm}$ of the section consists of grey and yellow fine sand, rich in plant detritus and peat lenses.

SAO4. The lower part of the section $(270-210 \mathrm{~cm})$ is formed by a layer of fine-grained grey sand (Fig. 7). The upper layer, $210-105 \mathrm{~cm}$, is composed of an interbedding of fine-grained grey sand, peaty layers and silt layers, including numerous plant remains. The 105$95 \mathrm{~cm}$ layer is a peat, overlaid by $c .10 \mathrm{~cm}$ of silt, rich in plant remains. The upper $85-70 \mathrm{~cm}$ layer is a nondecomposed peat layer overlain by sandy silt (70$45 \mathrm{~cm})$ and well-decomposed peat $(45-10 \mathrm{~cm})$. The uppermost $10 \mathrm{~cm}$ is the modern soil.

Chronology: - In total, 18 AMS and conventional ${ }^{14} \mathrm{C}$ ages were obtained from the SAOI sequence (Table 2). A reasonable age sequence, combined with an apparent lack of erosional events or hiatuses, suggests that the sediments were formed continuously during the last $c$. 30000 radiocarbon years. A few age reversals reflect the reworked character of the dated material. We believe that the youngest dates are more reliable, as there is no evidence of possible contamination of the sediments by younger organic material. All ${ }^{14} \mathrm{C}$ dates assumed as reworked (italicized, Table 2) were not considered for the palaeoenvironmental reconstructions.

Three conventional ${ }^{14} \mathrm{C}$ ages were obtained from sequence SAO3, and only one age from SAO4 (Table 2). The dates indicate that $\mathrm{SAO} 3$ and $\mathrm{SAO} 4$ sections accumulated during the late Holocene.

Pollen. - There are two pollen diagrams for sequence SAOI (Figs 4, 5), both zoned by visual inspection. Fig. 4 is based an analysis by J. Hahne, whereas Fig. 5 is based on an analysis by G. N. Shilova. The diagrams supplement each other, as Hahne's analysis mostly covers the Holocene, whereas Shilova's the Pleistocene part of the section. In the overlap, both diagrams reflect similar trends, but differ in the number and amount of identified palynomorphs. The differences may be due partly to the different techniques used for pollen treatment, but may also reflect different palynological training.

The pollen analysis of J. Hahne (Fig. 4) shows a lower limit for PZ-I at a depth of $2520 \mathrm{~cm}$. The upper limit of PZ-I at about $600-\mathrm{cm}$ depth is less clear because of sparse samples. PZ-I is characterized by very low pollen concentrations and the presence of large amounts of reworked palynomorphs. The pollen spectra are 


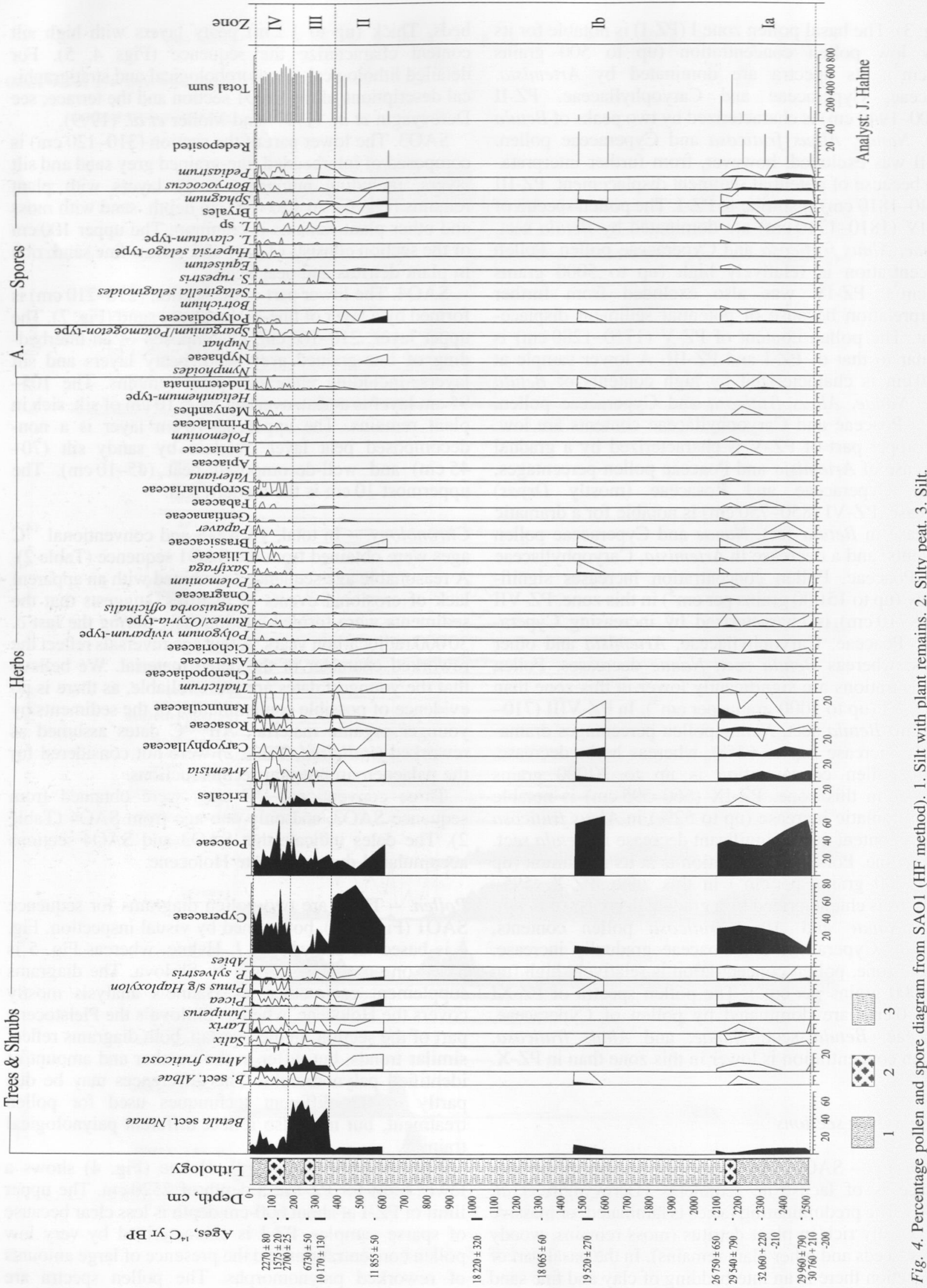




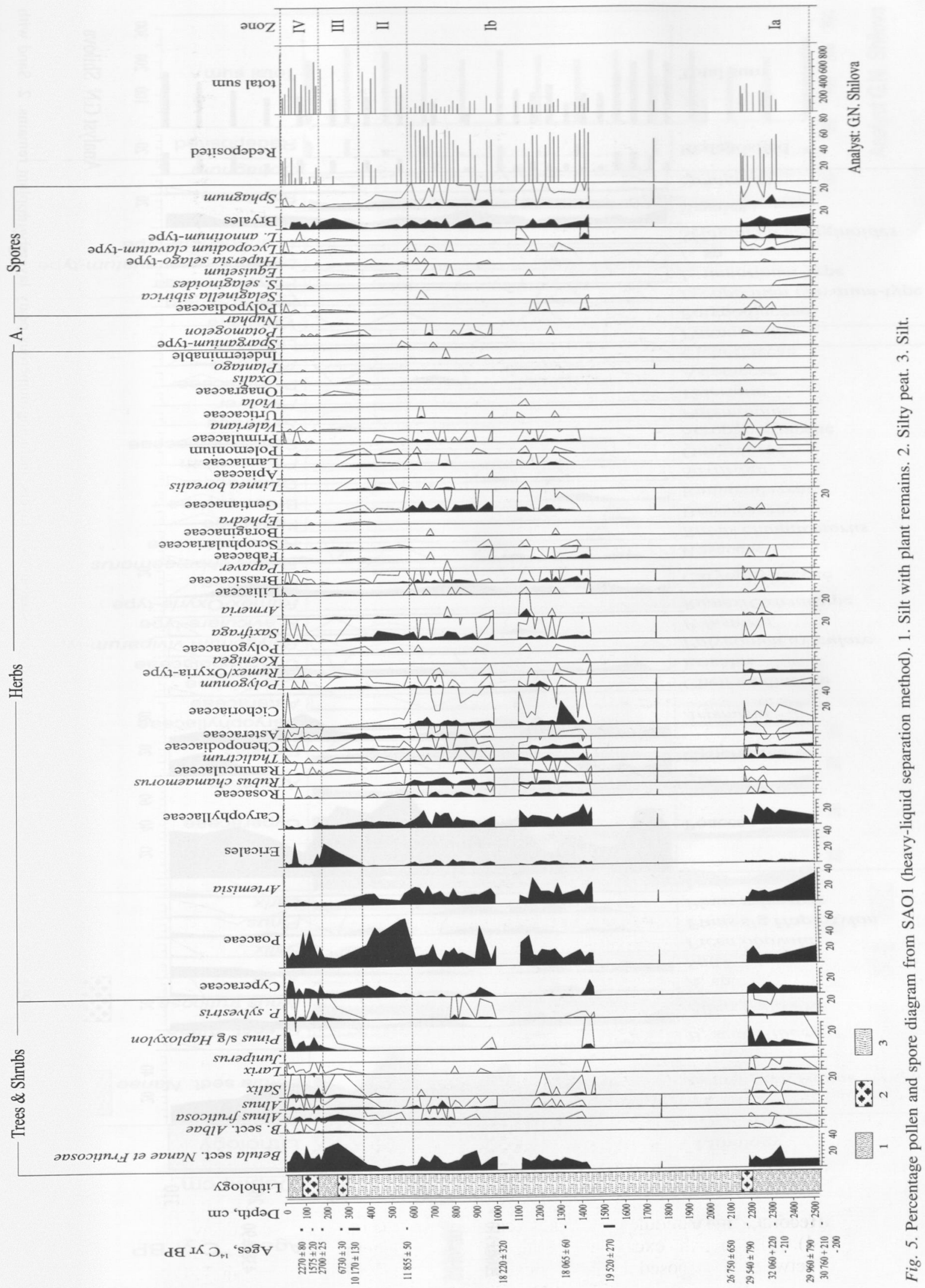




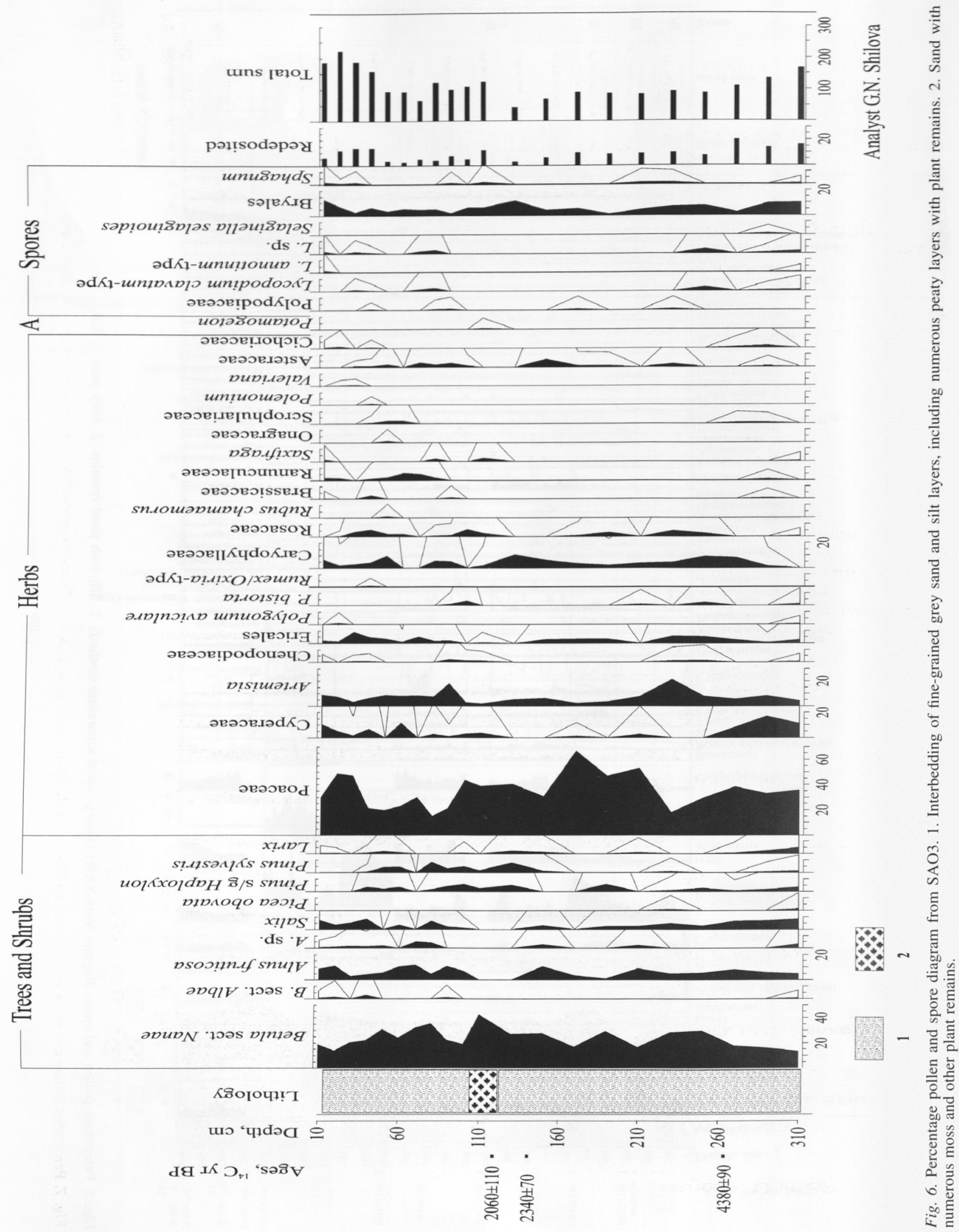




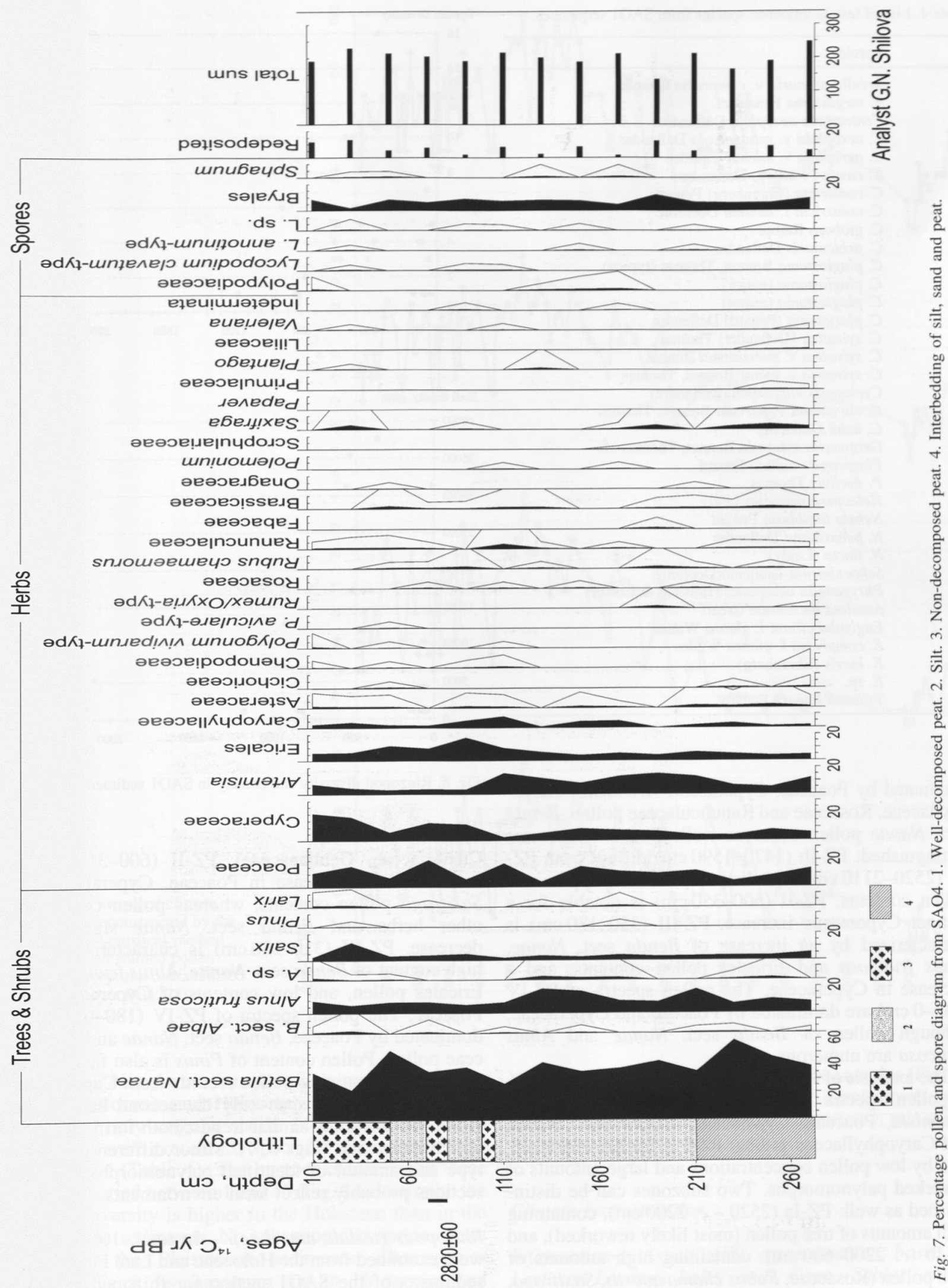


Table 4. List of testate amoebae species from SAO1 sequences,

\begin{aligned} \hline $\mathrm{N} &$ Species \\ \hline 1 & Arcella arenaria v. compressa Chardez \\ 2 & A. megastoma Penard cf. \\ 3 & Centropyxis aerophila Deflandre \\ 4 & C. aerophila v. sphagnicola Deflandre \\ 5 & C. aerophila v. minuta Chardez \\ 6 & C. cassis (Wallich) Deflandre \\ 7 & C. constricta (Ehrenberg) Penard \\ 8 & C. constricta f. minima Decloitre \\ 9 & C. gibbosa Rampi \\ 10 & C. orbicularis Deflandre \\ 11 & C. plagiostoma Bonnet, Thomas (typica) \\ 12 & C. plagiostoma (major) \\ 13 & C. plagiostoma (minor) \\ 14 & C. platystoma (Penard) Deflandre \\ 15 & C. sylvatica (Deflandre) Thomas \\ 16 & C. sylvatica v. microstoma Bonnet \\ 17 & C. sylvatica v. minor Bonnet, Thomas \\ 18 & Cyclopyxis eurystoma (Deflandre) \\ 19 & C. eurystoma v. parvula Bonnet, Thomas \\ 20 & C. kahli Deflandre \\ 21 & Geopyxella sylvicola Bonnet, Thomas cf. \\ 22 & Plagiopyxis callida Penard \\ 23 & P. declivis Thomas \\ 24 & Heleopera petricola Leidy \\ 25 & Nebela bigibbosa Penard \\ 26 & N. penardiana Deflandre \\ 27 & N. tincta (Leidy) \\ 28 & Schoenbornia humicola Decloitre \\ 29 & Phryganella acropodia (Hertwig \& Lesser) \\ 30 & Assulina muscorum Greeff \\ 31 & Euglypha ciliata f. glabra Wailes \\ 32 & E. compressa f. glabra Wailes \\ 33 & E. laevis (Ehrenberg) \\ 34 & E. sp. \\ 35 & Trinema lineare Penard \\ \hline & \end{aligned}

dominated by Poaceae, Cyperaceae, Artemisia, Caryophyllaceae, Rosaceae and Ranunculaceae pollen. Betula sect. Nanae pollen occur as well. Two subzones are distinguished: PZ-Ib $(1470-1590 \mathrm{~cm})$ differs from PZIa $(2520-2110 \mathrm{~cm})$ by distinctly lower Cyperaceae pollen contents, PZ-II $(600-350 \mathrm{~cm})$ is notable for a distinct Cyperaceae increase. PZ-III $(350-180 \mathrm{~cm})$ is characterized by an increase of Betula sect. Nanae, Alnus fruticosa and Ericales pollen contents, and a decrease in Cyperaceae. The pollen spectra of PZ-IV $(180-0 \mathrm{~cm})$ are dominated by Poaceae and Cyperaceae, although pollen of Betula sect. Nanae and Alnus fruticosa are numerous.

The analysis of G. N. Shilova (Fig. 5) shows that PZ1 pollen spectra $(2520-600 \mathrm{~cm})$ are dominated by Artemisia, Poaceae, Cyperaceae, Betula sect. Nanae and Caryophyllaceae pollen. PZ-I is further characterized by low pollen concentrations and large amounts of reworked palynomorphs. Two subzones can be distinguished as well: PZ-Ia $(2520-c .2200 \mathrm{~cm})$, containing high amounts of tree pollen (most likely reworked), and PZ-Ib (c. 2200-600 cm), containing high amounts of herb pollen (Rosaceae, Rubus chamaemorus, Saxifraga,
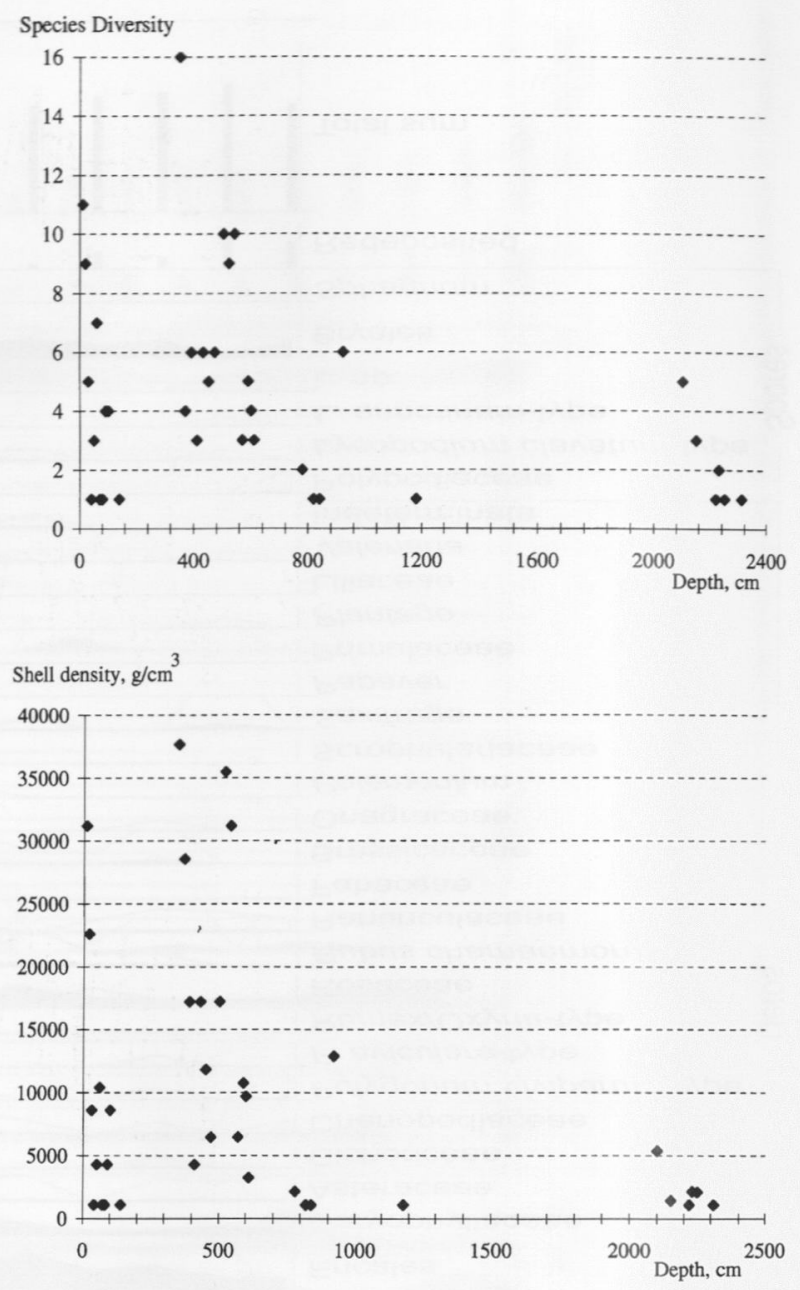

Fig. 8. Rhizopod diversity and density in SAO1 sediments.

Cichoriaceae, Gentianaceae). PZ-II $(600-310 \mathrm{~cm})$ is notable for an increase in Poaceae, Cyperaceae and Saxifraga pollen contents, whereas pollen content of other herbs and Betula sect. Nanae significantly decrease. PZ-III $(310-180 \mathrm{~cm})$ is characterized by a high content of Betula sect. Nanae, Alnus fruticosa and Ericales pollen, and low contents of Cyperaceae and Poaceae. The pollen spectra of PZ-IV $(180-0 \mathrm{~cm})$ are dominated by Poaceae, Betula sect. Nanae and Cyperaceae pollen. Pollen content of Pinus is also fairly high.

The two remaining pollen records from Cape Sabler (SAO3 and SAO4) span only the second half of the Holocene and show similar trends; both form only one pollen zone each (Figs 6, 7). Minor differences in the type and amount of identified palynomorphs in these sections probably reflect local environments.

Rhizopods (testate amoebae). - In total, 106 samples were examined from the Holocene and Late Pleistocene sediments of the SAO1 section for rhizopods (testate 
Fig. 9. The averaged climate anomalies, reconstructed by the information-statistical method (IS), using all studied pollen spectra (except the contaminated ones from core PG1228).
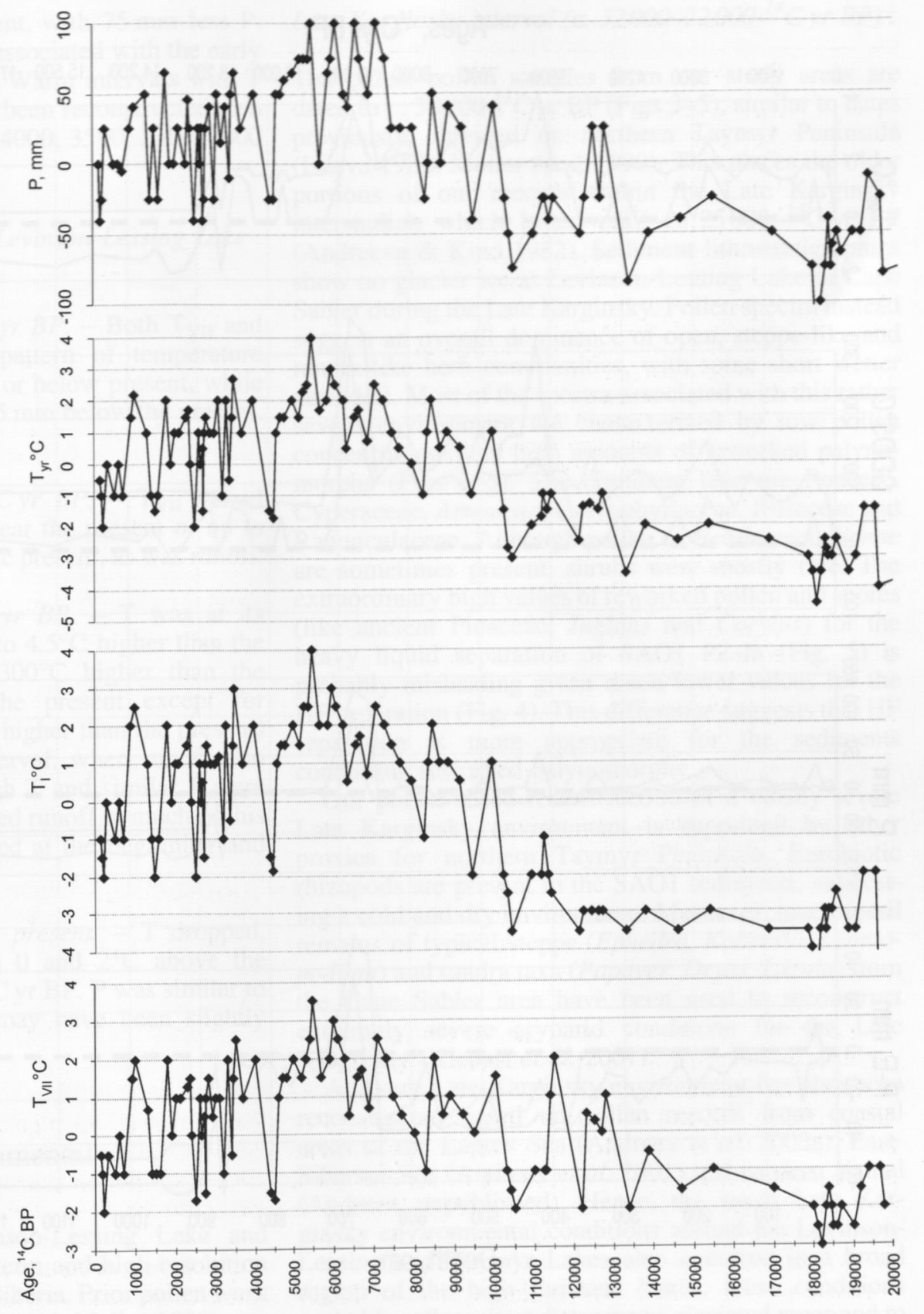

amoebae). None were found in 70 samples, including both Pleistocene and Holocene levels. Five samples contained only singular shells. In the 36 cases where rhizopods were present, 35 species, varieties and forms were found (Table 4). The number of species in these samples varied between 1 and 16 (Fig. 8). Generally, the species diversity is higher in the Holocene than in the Pleistocene sediments. No sphagnophilic species were found in the Pleistocene sediments. The species diversity is at its maximum (up to 16 species and infraspecific taxa) in the late Holocene samples (Fig. 8); the dominant complex consists of Centropyxis constricta f. minor, C. aerophila, C. sylvatica v. minor and C. eurystoma v. parvula.

\section{Climate reconstruction}

Information-statistical (IS) reconstruction based on Levinson-Lessing Lake and Cape Sabler pollen 


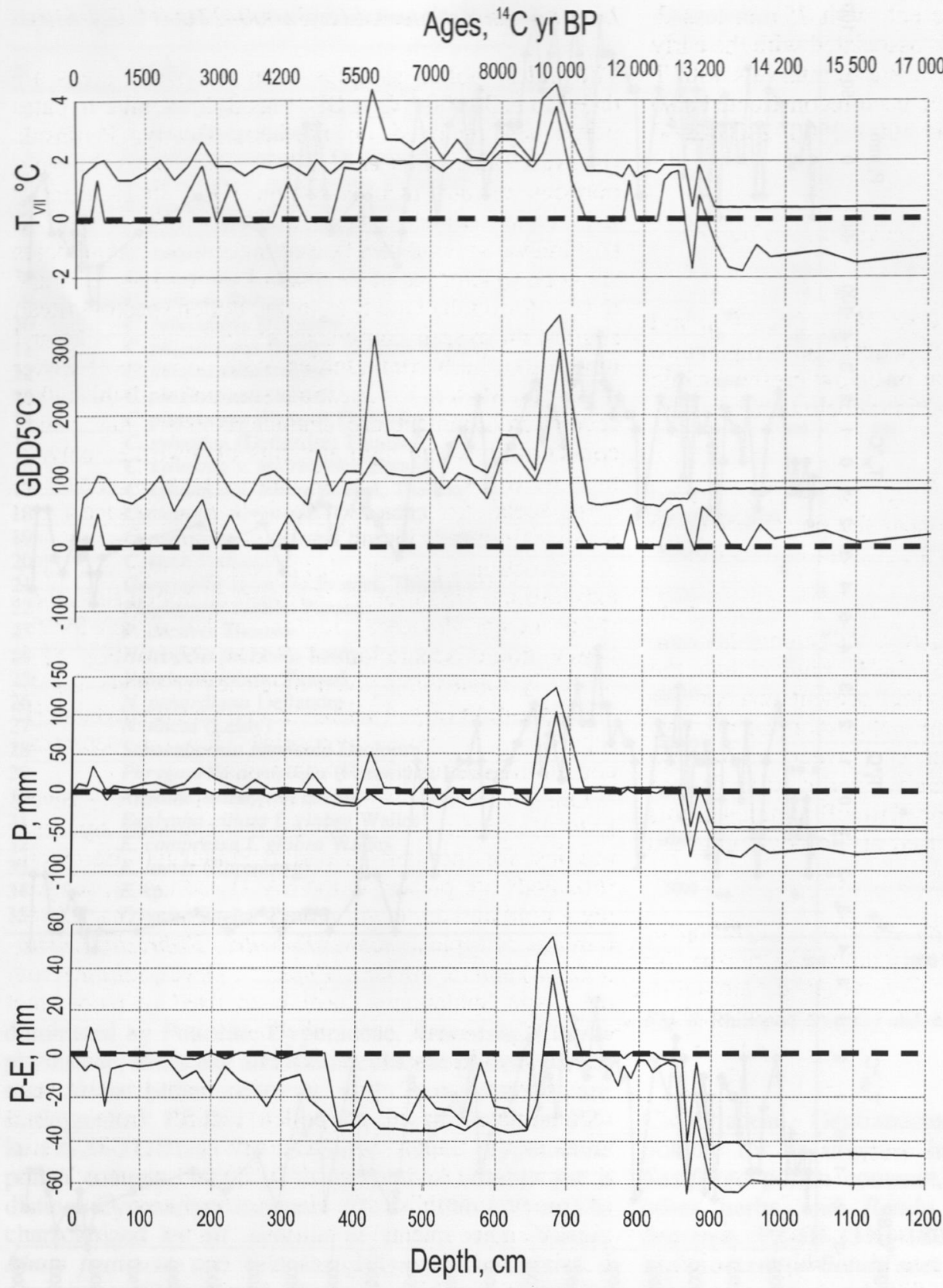

Fig. 10. Climate reconstruction from Levinson-Lessing Lake pollen record with the best modern analogue method (BMA). Two lines delimit a range between minimum and maximum values from the set of 10 modern analogues for each fossil spectrum. records c. 30000 to c. $20000{ }^{14}$ C yr BP. - Temperatures at c. $30000{ }^{14} \mathrm{C}$ yr BP were below modern values, probably by about $2-5^{\circ} \mathrm{C}$ depending on the season (winter $\mathrm{T}$ more depressed). Precipitation was also lower, probably by about $50-100 \mathrm{~mm}$. A subsequent climate amelioration may have occurred c. $27000 \mathrm{yr}$ ${ }^{14} \mathrm{C}$ BP with T and P slightly above the present. Shortly after, cold, dry conditions returned, similar to those $c$. $30000{ }^{14} \mathrm{C}$ yr BP, and persisted until at least $c .20000$ ${ }^{14} \mathrm{C}$ yr BP.
About $20000{ }^{14} \mathrm{C}$ yr BP to the present. - An extremely cold and dry climate is reconstructed for the Sartan stadial (equivalent to Late Weichselian), with $\mathrm{T}$ about $3-6^{\circ} \mathrm{C}$ below the present (seasonally dependent) and $\mathrm{P}$ up to $100 \mathrm{~mm}$ lower than today (Fig. 9). A warming event at the end of the Sartan stadial (equivalent to Bølling?) probably had $\mathrm{T}_{\mathrm{VII}}$ and $\mathrm{P}$ slightly higher than today, but $\mathrm{T}_{\mathrm{yr}}$ as much as $3^{\circ} \mathrm{C}$ lower. Later, during the Allerød (?), T and P were probably even higher (Fig. 9). A subsequent cooling (Younger Dryas?) reached values 
about $2-3.5^{\circ} \mathrm{C}$ below the present, with $75 \mathrm{~mm}$ less $\mathrm{P}$. The first Holocene warming is associated with the early Preboreal, c. $10000{ }^{14} \mathrm{C}$ yr BP. Warm intervals with T and $\mathrm{P}$ higher than present have been reconstructed also for c. 9000, 8500, 8000-5500, 4000, 3500, 2300-2000 and $1000{ }^{14} \mathrm{C}$ yr BP (Fig. 9).

\section{BMA reconstruction based on Levinson-Lessing Lake pollen record}

About 17000 to c. $13000{ }^{14}$ Cyr BP. - Both $\mathrm{T}_{\mathrm{VII}}$ and GDD5 curves show similar pattern of temperature trends (Fig. 10). $\mathrm{T}_{\mathrm{VII}}$ was near or below present, while $\mathrm{P}$ was much lower, about $50-75 \mathrm{~mm}$ below the present. Runoff was also much lower.

About 13000 to c. $10000{ }^{14}$ Cyr BP. - $\mathrm{T}_{\mathrm{VII}}$ varied considerably but was mostly near the present or up to $2{ }^{\circ} \mathrm{C}$ warmer. P was similar to the present, as was runoff.

About 10000 to c. $5500{ }^{14} \mathrm{Cyr} \mathrm{BP}$. - T was at its maximum, with July values 2 to $4.5^{\circ} \mathrm{C}$ higher than the present. GDD5 was 100 to $300^{\circ} \mathrm{C}$ higher than the present. $\mathrm{P}$ was similar to the present except for maximum values (50-130 $\mathrm{mm}$ higher than the present) near the beginning of this interval, when runoff also reached its maximum. The high $\mathrm{T}$ and similar $\mathrm{P}$ were probably the cause of the reduced runoff in much of this interval. The highest $\mathrm{T}$ occurred at the beginning and end of this interval.

About $5000{ }^{14} \mathrm{C} \mathrm{yr} \mathrm{BP}$ to the present. - $\mathrm{T}$ dropped, with $\mathrm{T}_{\mathrm{VII}}$ fluctuating between 0 and $2^{\circ} \mathrm{C}$ above the present during the last $5000{ }^{14} \mathrm{C}$ yr BP. P was similar to the present, although runoff may have been slightly lower.

\section{Discussion: palaeoenvironmental reconstructions}

The pollen data from Levinson-Lessing Lake and Cape Sabler are the first long-term and high-resolution records from northern Central Siberia. Prior pollen work on Levinson-Lessing Lake (Hahne \& Melles 1999) was based on the single ${ }^{14} \mathrm{C}$ date and correlation with the pollen chronology published by Khotinskiy (1984). Although our pollen zonation is similar to that of Hahne \& Melles (1999), there are significant differences in the environmental and chronological interpretation. Moreover, in the sections below, we compare our record with radiocarbon-dated environmental records from adjacent areas of Taymyr (Belorusova \& Ukraintseva 1980; Nikol'skaya 1980; Nikol'skaya et al. 1980; Andreeva \& Kind 1982; Belorusova et al. 1987; Velichko et al. 1997; Andreev \& Klimanov 2000; Andreev et al. 2002b; Andreev et al. in press).
Late Karginsky interval (c. $32000-22000{ }^{14}$ C yr BP)

The oldest pollen samples from our study areas are dated to $c .30000{ }^{14} \mathrm{C}$ yr BP (Figs 3-5), similar to dates previously obtained on northern Taymyr Peninsula (Isaeva 1982; Möller et al. 1999). This places the older portions of our records within the Late Karginsky interstadial, which lasted until c. $25000{ }^{14} \mathrm{C}$ yr BP (Andreeva \& Kind 1982). Sediment lithostratigraphies show no glacier ice at Levinson-Lessing Lake or Cape Sabler during the Late Karginsky. Pollen spectra instead suggest an overall dominance of open, steppe-like and tundra-like herb communities, with some short wetter period(s). Most of the spectra associated with this rather severe environment are characterized by low pollen concentrations and high amounts of reworked palynomorphs (Figs 3-5). The dominant taxa are Poaceae, Cyperaceae, Artemisia, Caryophyllaceae, Rosaceae and Ranunculaceae. Although pollen of Betula sect. Nanae are sometimes present, shrubs were mostly rare. The extraordinary high values of reworked pollen and spores (like ancient Pinaceae, Juglans and Corylus) for the heavy liquid separation of SAO1 PZ-Ia (Fig. 5) is probably misleading given much lower values for the HF separation (Fig. 4). This difference suggests that HF separation is more appropriate for the sediments containing reworked palynomorphs.

Our pollen-based reconstruction of a mostly severe Late Karginsky environment is supported by other proxies for northern Taymyr Peninsula. Eurobiotic rhizopods are present in the SAO1 sediments, suggesting a cold and dry environment. Moreover, macrofossil remains of typical steppe (Ephedra, Kobresia, Leontopodium) and tundra taxa (Papaver, Dryas, Luzula) from the Cape Sabler area have been used to reconstruct extremely severe cryoarid conditions for the Late Karginsky (Kienast et al. 2001).

A severe Late Karginsky environment has also been reconstructed based on pollen records from coastal areas of the Laptev Sea (Andreev et al. 2002a), EastSiberian Sea (Andreev et al. 2001) and western Yamal (Andreev unpublished). Hence, the harsh Late Karginsky environmental conditions around the LevinsonLessing and Taymyr Lakes also occurred in a broad region of the high Eurasian North; these conditions probably reflect short distances to glaciated areas and to the Arctic Ocean.

Unlike the northern Taymyr and other northern areas during the Late Karginsky interstadial, the southern Taymyr probably experienced much less severe conditions. In the south, northern taiga or forest-tundra vegetation was present (Andreeva \& Kind 1982; Andreev et al. 2002b). Because this southern area is presently treeless, the climate was warmer than the present.

Although environmental conditions on northern Taymyr during the Late Karginsky interstadial were most often severe, the IS-based climate reconstructions 
suggest some climate amelioration $c .27000 \mathrm{yr}{ }^{14} \mathrm{C}$ BP. This reconstruction is supported by a higher density of testacean shells in the Cape Sabler records, and especially by finds of rhizopods typical of wetter habitats (Arcella megastroma cf. and Plagiop:xis callida). Although a bud of Populus tremula $(26750 \pm 650 \mathrm{yr}$ BP) from the Cape Sabler area (SAOI) has been used to suggest that $T_{\text {VII }}$ was up to $6^{\circ} \mathrm{C}$ higher than today (Kienast et al. 2001), this bud may have been reworked. The Cape Sabler pollen records (Figs 4, 5) show that Populus tremula was probably unable to grow in this area during the Karginsky time. Moreover, it probably did not grow in southern Taymyr either (Andreeva \& Kind 1982; Andreev et al. 2002b). The Cape Sabler sediments also contain significant amounts of well-preserved and obviously reworked tree and shrub pollen (including exotic taxa such as Juglans, Corylus, Carpinus). Therefore, even if climate ameliorated during a portion of Late Karginsky time, it is unlikely that the local climate was significantly warmer than today.

\section{Interval c. $26000-20000^{14} \mathrm{C}$ yr BP}

Pollen spectra for the $c .26000-20000{ }^{14} \mathrm{C}$ yr BP interval, limited to Levinson-Lessing core PG1228, show conditions similar to the Late Karginsky: open steppe-like vegetation (Poaceae and Artemisia dominate) with some tundra-like communities (Betula sect. Nanae, Salix, Caryophyllaceae and other herb taxa). This result is based on PZ-III and PZ-V of PG1228. Two other pollen zones that seem to fall within this age interval, PZ-II and PZ-IV, were excluded because of potential displacement during coring (see above). The generally severe climate conditions for the interval $c$. $26000-20000{ }^{14} \mathrm{C}$ yr BP on the northern Taymyr Peninsula were similar to those reconstructed for the Laptev Sea region from pollen records (Andreev et al. 2002a).

\section{Sartan interval (c. $20000-10000{ }^{14} \mathrm{C}$ yr BP)}

Steppe-like vegetation dominated the northern Taymyr Peninsula during the Sartan (Late Weichselian Stadial, c. $22000-10000{ }^{14} \mathrm{C}$ yr BP), although tundra-like communities with Betula sect. Nanae, Salix and Cyperaceae were also widespread. Pollen spectra in Levinson-Lessing core PG1228 contain large amounts of Poaceae, Artemisia, Caryophyllaceae, Ranunculaceae, Cichoriaceae and other herb taxa (upper part of PZ-V and PZ-Ib; Figs 4, 5). Macrofossil remains in Cape Sabler profile SAO $1,{ }^{14} \mathrm{C}$ dated to $18065 \pm 60 \mathrm{yr}$ $\mathrm{BP}$, also show dominant steppe xerophytes and tundra cryophytes (Kienast et al. 2001). Moreover, very few rhizopod shells are found in the Sartan sediments (Fig. 8 ), which is also typical for Sartan sediments from the Laptev Sea region (Bobrov et al. in prep.). Thus, pollen, macrofossils and rhizopod shells all suggest an extre- mely cold climate during the Sartan interval. This is reflected in the IS and BMA reconstructions, which show the coldest climate during the Sartan (Figs 9, 10). Reconstructions of the LGM climate in northern Eurasia suggest that $T_{I}$ in Siberia were 7 to $15^{\circ} \mathrm{C}$ colder than the present and $\mathrm{T}_{\mathrm{VII}} 1$ to $7^{\circ} \mathrm{C}$ colder, while $P$ was 100 to $300 \mathrm{~mm}$ lower than the present (Tarasov et al. 1999).

We suspect a warming at the end of the Sartan Stadial (Bølling?) as shown by a gradual decrease of Artemisia and Poaceae and increasing Cyperaceae and Rosaceae (mostly Dryas) pollen percentages in the upper part of Levinson-Lessing core PG1228 PZ-V (Fig. 3).

In contrast to the unclear warming signal (Bølling?), there is a distinct warming in the next youngest pollen zone in core PG1228 (PZ-VI), which can probably be correlated to the Allerød interstadial. Its age in PG1228 is constrained by correlation with pollen records from the adjacent areas (Velichko et al. 1997, 2002; Andreev et al. 2002b; Andreev et al. in press). Its age in the Cape Sabler SAO1 section is constrained by radiocarbon dates of $11855 \pm 50$ and $10170 \pm 130 \mathrm{yr} \mathrm{BP}$. The warming in core PG1228 is demonstrated by a dramatic increase of Betula sect. Nanae, Salix and pollen concentration, and significant decrease of Artemisia, Poaceae and other herb taxa pollen contents (Fig. 3). This same warming is expressed in SAO1 PZ-II in Fig. 5 with increases in Poaceae and Cyperaceae and decreases of Artemisia, Caryophyllaceae, Cichoriaceae, Gentianaceae, Rosaceae and other herbs. The high values of Cyperaceae pollen and low values of Artemisia, Caryophyllaceae, Rosaceae, Ranunculaceae and other herbs in the PZ-II in Fig. 4 can also be interpreted as a response of local vegetation to a wetter and slightly warmer climate. The occurrence of eurobiotic Testacea shells throughout the SAOI sediments and the presence of soil and sphagnophilic species also signal a warm climate. Finally, both climate reconstruction methods suggest that $\mathrm{T}_{\mathrm{VII}}$ was up to $2^{\circ} \mathrm{C}$ higher than today (Figs 9, 10). Similar results are obtained from pollen records in the adjacent areas (Velichko et al. 1997, 2002; Andreev et al. 2002b; Andreev et al. in press).

A cooling of approximately Younger Dryas age is expressed in both core PG1228 and in section SAO-1. Pollen Zone-VII of PG1228 shows an increase of Cyperaceae, Poaceae, Caryophyllaceae, Artemisia and other herb taxa pollen content and decreasing Betula sect. Nanae contents and pollen concentration. Similar increases of Artemisia, Asteraceae, Rosaceae, Ranunculaceae and some other herb taxa occur in SAO PZ-II (Fig. 4) and in the upper part of SAO PZ-II (Fig. 5). Overall, these pollen spectra show that steppe communities became more dominant than during the prior warm period (Allerød?). Similar changes occurred in records from adjacent areas of Taymyr (Nikol'skaya 1980; Nikol'skaya et al. 1980; Velichko et al. 1997, 2002; Andreev \& Klimanov 2000; Andreev et al. 2002b). 


\section{Holocene (c. 10000-0 ${ }^{14} \mathrm{C} \mathrm{yr} \mathrm{BP}$ )}

Numerous and substantial environmental changes occurred at the Late Glacial/Preboreal transition on the northern Taymyr Peninsula. In core PG1228 PZVIII, Betula pollen percentages and total pollen concentration increased sharply while herb values decreased (Fig. 3). Similarly, SAOI pollen records (PZ-III in Fig. 4) show increases of Betula sect. Nance and Ericales pollen percentages, radiocarbon-dated to $c$. 10200 yr BP. Dwarf birches, locally in mosaics with Ericales communities, dominated the vegetation in the area. Rhizopod species diversity increased and its spectra include some sphagnophilic, coarse-humus rhizopods (species from Heleopera, Nebela and Triennia genera) and calceophilic Centropyis plagiostoma (Fig. 8). These changes suggest a much warmer and wetter environment than before $c .10000{ }^{14} \mathrm{C}$ yr BP. Our climate reconstructions have quantified this environment, showing that the early Preboreal warming $c$. $10000{ }^{14} \mathrm{C}$ yr BP resulted in $\mathrm{T}_{\mathrm{VII}} 3-4^{\circ} \mathrm{C}$ higher than the present and $P$ about $100 \mathrm{~mm}$ higher (Figs 9, 10). A climate change of similar magnitude is recorded at a number of Northern Eurasian locations (e.g. Velichko et al. 1997, 2002; Andreev \& Klimanov 2000; Andreev et al. 2002b).

The early Holocene was a period of higher-thanpresent temperatures on northern Taymyr Peninsula. Alder arrived locally about $8800-8500{ }^{14} \mathrm{C}$ yr BP as shown by the dramatic increases in Alnus fruticosa pollen content (up to $52 \%$ ) and total pollen concentration (up to 48000 grains per $\mathrm{cm}^{3}$ ) in PZ-IX of core PG1228 (Fig. 3) and a slight increase in Alntus pollen content at the bottom of PZ-III in section SAOl (Figs 4, 5). Macrofossil remains of Alnus fruticosa, dated to $9300 \pm 100,8850 \pm 50$ and $8220 \pm 120{ }^{14} \mathrm{C}$ yr BP, have also been found north of its present distribution, close to the investigated sites (Nikol'skaya et al. 1980; Kremenetski et al. 1998). Vegetation cover was probably similar to the modern southern (shrub) tundra, where Betula nana, Salix and Alnus fruticosa dominate. The early Holocene Alnus fruticosa was probably restricted to well-protected habitats, as it is in the modern southern tundra zone. Generally, the northern limit of Larix forests with Alnus fruticosa was further north than today on the Taymyr Peninsula about 8600 $8400{ }^{14} \mathrm{C}$ years ago (Andreev et al. 2002b). At that time, during the so-called Boreal thermal optimum, the Arctic Ocean had a weaker influence on the Taymyr environment than today because of a lower sea level and, thus, a longer distance to the coast (Velichko et al. 1997; Andreev et al. 2002b). Summer insolation, another important factor, was still much higher than modern.

Betula sect. Nanae and Almus fruticosa pollen content gradually decreases between $c .9000$ and $5000{ }^{14} \mathrm{C}$ yr $\mathrm{BP}$ in PZ-X of PG1228 (Fig. 3) reflecting their reduction in the local vegetation. Although decreasing, the percentages were still quite high and show that these shrubs remained either within or very close to the study sites. Coinciding with these decreases are gradual increases in Cyperaceae, Poaceae and Polypodiaceae. These changes most likely reflect rising sea level, declining summer insolation and onset of cooler, more maritime climate during the Atlantic period (Wolf et al. 2000). Thus, the shrubby tundra dominated by Betula sect. Nanae, and probably with Almus fruticosa as codominant in some places, was gradually replaced with herb-tundra communities (mostly with Cyperaceae and Poaceae) between c. 8000 and $4500{ }^{14} \mathrm{C}$ yr BP. Both climate reconstruction methods suggest a climate warmer than today during the Atlantic period (Figs 9, $10)$.

Holocene climate conditions appear to have deteriorated strongly after $c .4500{ }^{14} \mathrm{C}$ yr BP to values similar to the present, where they remained for much of the late Holocene. Rhizopods became absent or had low species diversity and density (Fig. 8). There were also substantial decreases in total pollen concentration, Betula sect. Nanae and Almus fruticosa pollen contents (PZ-XI, Fig. 3; PZ-IV, Figs 4, 5). Although reduced, these pollen taxa remained common in all late Holocene spectra (Figs 3-7). We believe that they mostly represent long-distance pollen, especially Alnus. A long-distance origin of arboreal pollen is also indicated by the increase of Pinus, Picea and Larix percentages. The present northern distributional limit of these taxa is a few hundred kilometres to the south. There are no Betula or Alnus shrubs in the Levinson-Lessing Lake area today despite modern pollen spectra with up to $20 \%$ of Betula sect. Namae and up to $10 \%$ of Almus fruticosa pollen (uppermost part of core PG1228). Thus, shrubless herb tundra has generally dominated the region since $c .4500 \mathrm{yr} \mathrm{BP}$. In well-protected local sites, however, dwarf Betula sect. Nancie might even have dominated the vegetation. Its local presence about $2800{ }^{14} \mathrm{C}$ yr BP is confirmed by macrofossil finds in profile SAO4 (Kienast et al. 2001).

Climate reconstructions (especially by the IS method) show a middle Holocene climate deterioration followed by conditions similar to the present (Figs 9, 10). Brief warming events interrupted the similar-topresent conditions of the late Holocene (warm events $c$. $4000,3500,2300-2000$ and $1000 \mathrm{yr}$ BP). Similarly dated climate fluctuations are recorded in many Northern Eurasian paleoenvironmental records (e.g. Velichko et al. 1997; Andreev \& Klimanov 2000; Andreev et al. 2001, 2002b.)

\section{Conclusions}

The first high-resolution, continuous pollen records for the northern Taymyr Peninsula reveal substantial vegetation and climate changes over the past 30000 ${ }^{14} \mathrm{C}$ yr BP, a period without any glacier cover. The oldest part of the record, corresponding to the Late 
Karginsky and the Sartan intervals, shows a steppe-like vegetation with Poaceae, Artemisia and Cyperaceae dominating. Tundra-like communities with Betula nana, Dryas and Salix were probably present in moister sites. The coldest climate occurred within the Sartan period at c. $18000{ }^{14} \mathrm{C}$ yr BP. Subsequent Lateglacial climate fluctuations probably correspond to interstadial warmings and the Younger Dryas cooling. The Lateglacial/Preboreal transition, c. $10300-10000{ }^{14} \mathrm{C}$ yr BP, is characterized by rapid warming and a change to shrubby tundra. Dwarf Betula and Salix. Alnus fruticosa arrived locally c. $9000-8500{ }^{14} \mathrm{C}$ yr BP; the early Holocene also included Betula sect. Nanae communities. These taxa occurred when temperature and precipitation were higher than present. Shrubby tundra probably existed until cooler conditions arrived during the early Subboreal period, c. $4000-3500{ }^{14} \mathrm{C}$ yr BP. The local vegetation developed into modern herb tundra at the end of the Subboreal period, $c .3000-2500{ }^{14} \mathrm{C} \mathrm{yr}$ BP. Brief warming events interrupted the similar-topresent conditions of the late Holocene (c. 4000, 3500, 2300-2000 and $1000 \mathrm{yr}$ BP.)

Acknowledgements. - We thank the participants of the 'Taymyr $1995^{\prime}$ and 'Taymyr/Severnaya Zemlya 1996' expeditions for their generous help in collecting samples. This research was made possible through the 'Taymyr' project of the German Ministry of Education and Research (Grant no. 03PL0I4A,B) and the project 'Natural climate variations from 10000 years to the present day (KIHZ)' of the Helmholtz Association of National Research Centers (HGF). Pavel Tarasov was also supported by the Russian Foundation for Fundamental Investigations (RFFI grant nos. 00-05-22000 and 0105-64471). We thank J. Hahne and G. N. Shilova for counting pollen and $\mathrm{C}$. Zich for collecting material for AMS dating from core 1228

\section{References}

Alexanderson, H., Hjort, Ch., Möller, P., Antonov, O. \& Pavlov, M. 2001: The North Taymyr ice-marginal zone, Arctic Siberia: a preliminary overview and dating. Global and Planetary Change $31,427-445$.

Andreev, A. A. \& Klimanov, V. A. 2000: Quantitative Holocene climatic reconstruction from Arctic Russia. Journal of Paleolimnology 24, 81-91.

Andreev, A. A., Klimanov, V. A. \& Sulerzhitsky, L. D. 2001: Vegetation and climate history of the Yana River lowland during the last 6400 yr. Quaternany Science Reviews 20, 259-266.

Andreev, A. A., Peteet, D. M., Tarasov, P. E., Filimonova, L., Romanenko, F. A. \& Sulerzhitsky, L. D. 2001: Late Pleistocene Interstadial Environment on Fadeyevsky Island, East Siberian Sea, Russia. Arctic, Antarctic, and Alpine Research 33, 28-35.

Andreev, A. A., Schirrmeister, L., Siegert, Ch., Bobrov, A. A., Demske, D., Seiffert, M. \& Hubberten, H.-W. 2002a: Paleoenvironmental changes in Northeastern Siberia during the Upper Quaternary: evidence from pollen records of the Bykovsky Peninsula. Polarforschung 70, 13-25.

Andreev, A. A., Siegert, C., Klimanov, V. A., Derevyagin, A. Yu., Shilova, G. N. \& Melles, M. 2002b: Late Pleistocene and Holocene vegetation and climate changes in the Taymyr lowland, Northern Siberia reconstructed from pollen records. Quaternary Research 57, 138-150.

Andreev, A. A., Tarasov, P. E., Klimanov, V. A., Melles, M., Lisitsina, O. M. \& Hubberten, H.-W. In press: Vegetation and climate changes around the Lama Lake, Taymyr Peninsula during the Late Pleistocene and Holocene reconstructed from pollen records. Quateman International.

Andreeva. S. M. \& Kind. N. V. 1982: Karginsky deposits. In Kind, N. V. \& Leonov, B. N. (eds.): Antropogen Taymyra. 78-114. Nauka, Moscow (in Russian).

Atlas Arktiki. 1985: GUGK, Moscow (in Russian).

Anisimov, 11. A. \& Pospelov, I. N. 1999: The landscape and geobotanical characteristics of the Levinson-Lessing Lake basin, Byrranga Mountains Central Taymyr. In Kassens, H., Bauch, H. A., Dmitrenko, I., Eicken, H., Hubberten, H.-W.. Melles, M., Thiede, J. \& Timokhov, L. (eds.): Land-Ocean Sistem in the Siberian Arctic: Dynamics and History, 361-376. SpringerVerlag, Berlin.

Belorusova, Zh. M. \& Ukraintseva, V. V. 1980: Paleogeography of Novaya River (Taymyr Peninsula) during the late Pleistocene and Holocene. Botanicheskiy Zhurnal 65, 368-379 (in Russian).

Belorusova, Zh. M., Lovelius, N. V. \& Ukraintseva, V. V. 1987: Regional characteristics of the Holocene environmental changes on Taymyr Peninsula. Botanicheskiy. Zhurnal 72, 610-618 (in Russian).

Berglund, B. E. \& Ralska-Jasiewiczowa, M. 1986: Pollen analysis and pollen diagrams. In Berglund, B. E. (ed.): Handbook of Holocene Palaeoecology and Palaeohydrology, 455-484. Interscience, New York.

Bolshiyanov, D. Yu. \& Anisimov, M. A. 1995: Investigations in the Levinson-Lessing Lake area. Geomorphological studies and landscape mapping. Russian-German cooperation: the expedition Taymyr 1994. Berichte zur Polarforschung 175, 9-13.

Clayden, S. L., Cwynar, L. C., MacDonald, G. M. \& Velichko, A. A. 1997: Holocene pollen and stomata from a forest site on the Taymyr Peninsula, Siberia. Arctic and Alpinc Research 29, 327333.

Derevyagin, A., Siegert, C., Troshin, E. \& Simonov, E. 1997 ; Permafrost landscapes and geomorphology of Cape Sabler. Russian-German cooperation: the expedition Taymyr/Severnaya Zemlya 1996. Berichte zur Polarforschung 237, 89-97.

Ebel, T., Melles, M. \& Niessen, F. 1999: Laminated sediments from Levinson-Lessing Lake, northern central Siberia: a 30,000 year record of environmental history? In Kassens. H., Bauch, H. A., Dmitrenko, I., Eicken, H., Hubberten, H.-W., Melles, M., Thiede, J. \& Timokhov, L. (eds.): Land-Ocean System in the Siberian Arctic: Dynamics and History, 425-435. Springer-Verlag, Berlin. Geokriologia SSSR. 1989: Nedra, Moscow, 250 pp. (in Russian).

Grimm, E. 1991: TILIA and TILIAGRAPH. Illinois State Museum, Springfield, Illinois.

Grosswald, M. G. 1998: Late-Weichselian ice sheet in Arctic and Pacific Siberia. Quaternary International 45/46, 3-18.

Grosswald, M. \& Hughes, T. J. 2002: The Russian component of an Arctic Ice Sheet during the Last Glacial Maximum. Quateman Science Reviews 2I, 121-146.

Guiot, J. 1990: Methodology of paleoclimatic reconstruction from pollen in France. Palaeogeography, Palaeoclimatology, Palaeoecology 80, 49-69.

Guiot, J. \& Goeury, C. 1996: PPPBASE, a software for statistical analysis of paleoecological and paleoclimatological data. Dendrochronologia 14, 295-300.

Hahne, J. \& Melles, M. 1997: Late and post-glacial vegetation and climate history of the south-western Taymyr Peninsula, Central Siberia, as related by pollen analysis of a core from Lake Lama. Vegetation History and Archaeobotany 6, 1-8.

Hahne, J. \& Melles, M. 1999: Climate and vegetation history of the Taymyr Peninsula since Middle Weichselian time: palynological evidence from lake sediments. In Kassens, H., Bauch, H. A., Dmitrenko, I., Eicken, H., Hubberten, H.-W., Melles, M., Thiede, J. \& Timokhov, L. (eds.): Land-Ocean System in the Siberian Arctic: Dynamics and History, 407-423. Springer-Verlag, Berlin.

Isaeva, L. L. 1982: Sartan deposits. In Kind, N. V. \& Leonov, B. N. (eds.): Antropogen Taymyra, 114-138. Nauka, Moscow (in Russian). 
Khotinskiy, N. A. 1984: Holocene climate changes. In Velichko, A. A., Wright, H. \& Barnosky, K. W. (eds.): Late Quatemary Enviromments of the Soviet Union, 179-200. University of Minnesota, Minneapolis.

Kienast, F. W., Siegert, C., Dereviagin, A. \& Mai, D.-H. 2001: Climate implications of Late Quaternary plant macrofossil assemblages from the Taymyr Peninsula, Siberia. Global and Planetary Change 31, 265-281.

Kienel, U., Siegert, C. \& Hahne, J. 1999: Late Quaternary paleoenvironmental reconstructions from a permafrost sequence (North Siberian Lowland, SE Taymyr Peninsula): a multidisciplinary case study. Boreas 28, 181-193.

Klimanov, V. A. 1984: Paleoclimatic reconstruction based on the information statistical method. In Velichko, A. A., Wright, H. \& Barnosky, K. W. (eds.): Late Quaternan Environments of the Soviet Union, 297-303. University of Minnesota, Minneapolis.

Kremenetski, C. V., Sulerzhitsky, L. D. \& Hantemirov, R. 1998: Holocene history of the northern range limits of some trees and shrubs in Russia. Arctic and Alpine Research 30, 317-333.

Leemans, R. \& Cramer, W. 1991: The IIASA Database for Monthly Values of Temperature, Precipitation and Cloudiness of Global Terrestrial Grid RR-91-18. International Institute for Applied Systems Analysis, Laxenburg.

Mangerud, J., Astakhov, V. \& Svendsen, J.-I. 2002: The extent of Barents-Kara ice sheet during the Last Glacial Maximum. Quaternary Science Reviews 21,111-119.

Melles, M., Siegert, C., Hahne, J. \& Hubberten, H.-W. 1996: Klimaund Umweltgeschichte des nördlichen Mittelsibiriens im Spätquartär - erste Ergebnisse. Geowissenschaften 14, 376-380.

Melles, M., Wand, U., Hermichen, W.-D., Bergemann, B., Bolshiyanov, D. Yu. \& Khrutsky, S. F. 1994: The expedition Norilsk/ Taymyr 1993 of the AWI research unit Potsdam. Berichte zur Polarforschung 148, 3-28.

Möller, P., Bolshiyanov, D. Yu. \& Bergstein, H. 1999: Weichselian geology and paleoenvironmental history of the central Taymyr Peninsula, Siberia, indicating no glaciation during the last global glacial maximum. Boreas 28, 92-114.

Niessen, F., Ebel, T., Kopsch, C. \& Fedorov, G. B. 1999: Highresolution seismic stratigraphy on the Taymyr Peninsula, Central Siberia. In Kassens, H., Bauch, H. A., Dmitrenko, I., Eicken, H., Hubberten, H.-W., Melles, M., Thiede, J. \& Timokhov, L. (eds.): Land-Ocean System in the Siberian Arctic: Dynamics and Histon;, 437-456. Springer-Verlag, Berlin.

Nikol'skaya, M. B. 1980: Paleobotanic characteristics of the Upper Pleistocene and Holocene deposits on the Taymyr. In Volkova, V. S. (ed.): Paleopalinologia Sibiri, 97-111. Nauka, Moscow (in Russian).
Nikol'skaya, M. B., Kind, N. V., Sulerzhitsky, L. D. \& Cherkasova, M. N. 1980: Geochronology and paleophytological characteristics of the Holocene in the Taymyr. In Ivanova, I. K. \& Kind, N. V. (eds.): Geokhronologia chenertichnogo perioda, 176-183. Nauka, Moscow (in Russian).

Overduin, P. P., Bolshiyanov, D. \& Ebel, T. 1996: Lake sediment sampling on Taymyr Peninsula. Russian-German cooperation: the expedition Taymyr 1995 and the expedition Kolyma 1995 of the ISSP Pushchino group. Berichte zur Polarforschung 211, $111-$ 121.

Siegert, C., Derevyagin, A. Yu., Shilova, G. M., Hermichen, W.-D. \& Hiller, A. 1999: Paleoclimate indicators from permafrost sequences in the Eastern Taymyr lowland. In Kassens, H., Bauch, H. A., Dmitrenko, I., Eicken, H., Hubberten, H.-W., Melles, M., Thiede, J. \& Timokhov, L. (eds.): Land-Ocean System in the Siberian Arctic: Dynamics and History, 477-499. SpringerVerlag, Berlin.

Tarasov, P. E., Andreev, A. A. \& Hubberten, H.-W. 2002: Quantitative climate reconstruction based on pollen data from Russian Arctic. Abstracts of European Geophysical XXVII General Assembly, Nice, France, 21-26 April 2002.

Tarasov, P. E., Peyron, O., Guiot, J., Brewer, S., Volkova, V. S., Bezusko, L. G., Dorofeyuk, N. I., Kvavadze, E. V., Osipova, I. M. \& Panova, N. K. 1999: Last Glacial Maximum climate of the former Soviet Union and Mongolia reconstructed from pollen and plant macrofossil data. Climate Dynamics 14, 227-240.

Tarasov, P. E. \& 27 others 1998: Present-day and mid-Holocene biomes reconstructed from pollen and plant macrofossil data from the former Soviet Union and Mongolia. Journal of Biogeography $25,1029-1053$.

Velichko, A. A., Andreev, A. A. \& Klimanov, V. A. 1997: The dynamics of climate and vegetation in the tundra and forest zone during the Late Glacial and Holocene. Quaternary International $41 / 42,71-96$.

Velichko, A. A., Catto, N., Drenova, A. N., Klimanov, V. A., Kremenetski, K. V. \& Nechaev, V. P. 2002: Climate changes in East Europe and Siberia at the Late Glacial-Holocene transition. Quaternary International 91, 75-99.

Wolf, B. B., Edwards, T. W. D., Aravena, R., Forman, S. L., Warner, B. G., Velichko, A. A. \& MacDonald, G. M. 2000: Holocene paleohydrology at treeline, north-central Russia, inferred from oxygen isotope records in lake sediment cellulose. Quatemary Research 53, 319-329.

Zhurbenko, M. P. 1995: Geobotanical studies. Russian-German cooperation: the expedition Taymyr 1994. Berichte zur Polarforschung 175, 25-26. 